OPEN ACCESS

Edited by: Heike Wulff,

University of California, Davis, United States

Reviewed by:

Robert I. Barkin,

Rush University Medical Center United States Todd M. Hillhouse,

University of Wisconsin-Green Bay, United States

${ }^{*}$ Correspondence: Salahadin Abdi sabdi@mdanderson.org

Specialty section: This article was submitted to

Neuropharmacology, a section of the journal

Frontiers in Pharmacology

Received: 27 August 2020 Accepted: 15 December 2020 Published: 02 February 2021

Citation:

Culp C, Kim HK and Abdi S (2021) Ketamine Use for Cancer and Chronic Pain Management.

Front. Pharmacol. 11:599721. doi: 10.3389/fphar.2020.599721

\section{Ketamine Use for Cancer and Chronic Pain Management}

\author{
Clayton Culp ${ }^{1}$, Hee Kee $\mathrm{Kim}^{2}$ and Salahadin $\mathrm{Abdi}^{2 *}$ \\ ${ }^{1}$ McGovern Medical School, University of Texas Health Science Center Houston (UTHealth), Houston, TX, United States, ${ }^{2}$ Division \\ of Anesthesiology, Department of Pain Medicine, Critical Care and Pain Medicine, The University of Texas MD Anderson Cancer \\ Center, Houston, TX, United States
}

Ketamine, an N-methyl-D-aspartate receptor antagonist, is widely known as a dissociative anesthetic and phencyclidine derivative. Due to an undesirable adverse event profile when used as an anesthetic it had widely fallen out of human use in favor of more modern agents. However, it has recently been explored for several other indications such as treatment resistant depression and chronic pain. Several recent studies and case reports compiled here show that ketamine is an effective analgesic in chronic pain conditions including cancer-related neuropathic pain. Of special interest is ketamine's opioid sparing ability by counteracting the central nervous system sensitization seen in opioid induced hyperalgesia. Furthermore, at the sub-anesthetic concentrations used for analgesia ketamine's safety and adverse event profiles are much improved. In this article, we review both the basic science and clinical evidence regarding ketamine's utility in chronic pain conditions as well as potential adverse events.

Keywords: analgesia, chronic pain, cancer pain, ketamine, ketamine infusion, mechanism of action, neuropathic pain

\section{INTRODUCTION}

Ketamine, a phencyclidine derivative, was first synthesized in the 1960s as a short-acting alternative to phencyclidine which also demonstrated lower occurrence rates of emergence delirium (Domino, 2010). The drug gained FDA approval for use as a sole or combine general anesthetic agent in 1970 with administration intravenously or intramuscular (Rosenbaum et al., 2020). While not currently FDA approved, there has been significant clinical evidence that suggests administration of ketamine at sub-anesthetic doses provides significant analgesic effects with limited side effects (Kronenberg, 2002). Indeed, intravenous ketamine infusions for chronic refractory pain are within the guidelines of the American Society of Anesthesiology (Cohen et al., 2018). Likewise, growing evidence supports alternative modes of delivery of ketamine in analgesia (Kronenberg, 2002). The purpose of this review is to highlight the current understanding of ketamine use in chronic pain management especially as it relates to cancer pain.

\section{CHEMISTRY, PHARMACOLOGY, AND PHARMACOGENOMICS}

\section{Ketamine Pharmacokinetics}

The proper IUPAC chemical name for ketamine is 2-(2-chlorophenyl)-2-(methylamino)cyclohexanone ketamine. It consists of two optical enantiomers, both of which can be seen in Figure 1, due to an asymmetric $\mathrm{C} 2$ carbon atom. It exhibits non-polarity and is therefore highly lipid soluble. While both the racemate mixture and (S)-Ketamine are clinically available as water soluble 


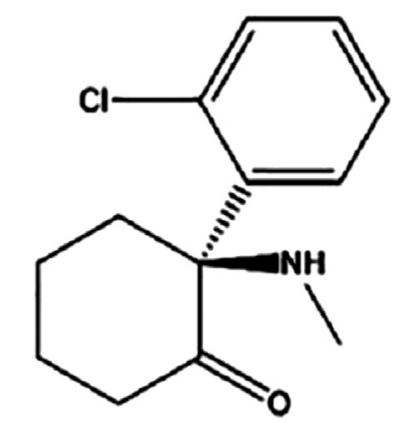

(S)-Ketamine

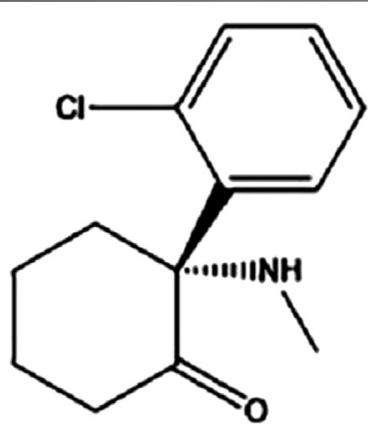

(R)-Ketamine
FIGURE 1 | Chemical structural of the two ketamine enanitomers.

powders, there are currently no commercial (R)-Ketamine solutions. This is likely due to the observation that (S)Ketamine is several times more potent at producing anesthetic and analgesic effects (Sinner and Graf, 2008).

In a study of healthy patients, the volume of distribution is estimated as $380-650 \mathrm{~L} / 70 \mathrm{~kg}$ while the oral bioavailability was found to be in the range of $7-20 \%$. The low bioavailability is due to a high first pass metabolism evidenced by the fact that clearance of ketamine was $83-121 \mathrm{~L} / \mathrm{h} / 70 \mathrm{~kg}$ which is in the range of liver blood flow. It can therefore be deduced that conditions such as cirrhosis which reduce hepatic blood flow will lower ketamine clearance (Dahan et al., 2011).

Initial metabolism of ketamine occurs via oxidation by the cytochrome P450 family of enzymes, most notably CYP3A4 and CYP2B6, which produces norketamine, 6-hydroxyketamine, and 4-hydroxyketamine. Norketamine retains pharmacologic activity and is considered the major metabolite as approximately $80 \%$ of ketamine is metabolized to this form. The remaining $20 \%$ is metabolized by one of two pathways to 4- or 6-hydroxyketamine before subsequently metabolized to hydroxy-norketamine (Kharasch and Labroo, 1992; Hijazi and Boulieu, 2002).

\section{Ketamine Drug Interactions}

Ketamine has been shown to have interactions on the metabolism and activity of many other drugs that must be considered when used clinically. Of special note is ketamine's reliance on the cytochrome P450 family of enzymes for its metabolism and degradation.

Rifampin, a well-known inducer of the CYP3A subfamily of enzymes, greatly reduces the area under the curve (AUC) for ketamine plasma concentration (14\% IV, $86 \%$ Oral) and reduced the maximum plasma concentration after oral ketamine by $81 \%$ while not significantly shortening half-life of the drug (Peltoniemi, et al., 2012a).

In contrast, patients given Clarithromycin demonstrated a 2.6-fold increase in maximum Ketamine plasma concentration due to inhibition of the enzyme CYP3A resulting in a selfreported increase in drug efficacy (Hagelberg et al., 2010). Grapefruit juice, another Cytochrome P450 inhibitor, increased the mean AUC for ketamine plasma concentration by 3 -fold and increased maximum plasma concentration of ketamine 2.1-fold while increasing half-life $21 \%$. The half-life and maximum concentration of ketamine's major metabolite norketamine were not significantly changed (Peltoniemi, et al., 2012b). In both studies investigating inhibition of ketamine metabolism no adverse events were noted, likely due to the use of a low dosage, however based on clinical experience it is presumed that adverse events would be more prevalent in patients taking ketamine and exposed to clarithromycin or grapefruit juice.

In addition to effects on the P450 family of enzymes, ketamine also inhibits many human UDP-glucuronosyltransferase (UGT) enzymes with the exception of UGT1A4. UGT2B4, UGT2B7, and UGT2B15 were inhibited with IC50's less than $<100 \mu \mathrm{M}$ ketamine. Of specific interests, inhibition of UGT2B7 is responsible for metabolism of Morphine and Codeine. At anesthetic doses, inhibition of this enzyme was clinically significant for metabolism for Morphine and Codeine while at analgesic doses the inhibition was only clinically significant for Codeine metabolism (Uchaipichat et al., 2011).

Another important drug interaction occurs with benzodiazepines which are frequently used to reduce dissociative symptoms of ketamine. Pre-treatment of surgical patients with diazepam results in higher plasma concentrations of ketamine and decreased ketamine clearance (Domino et al., 1984). Pre-treatment with diazepam also reduced the cardiac stimulation of ketamine and reduced initial infusion dose required compared to no premedication (Idvall et al., 1983). Haloperidol, an antipsychotic, has also been shown to modulate the CNS effects of sub-anesthetic ketamine and reduce ketamine-induced cognitive impairment (Krystal et al., 1999).

\section{Ketamine Pharmacogenomics}

With the increasing field-wide focus on personalized medicine, much work has also been done to understand how genetics can impact the metabolism and clearance of ketamine. Due to the wealth of information and availability of genetic information the cytochrome P450 family, especially CYP3A4 and CYP2B6 enzymes, have been the focus of much research.

One study surveyed the catalytic activity of thirty-eight CYP2C9 alleles on ketamine metabolism to norketamine. Compared with $2 \mathrm{C} 9{ }^{\star} 1$, three alleles $\left(2 \mathrm{C} 9{ }^{\star} 40,{ }^{\star} 49\right.$ and $\left.{ }^{\star} 51\right)$ demonstrated dramatically increased intrinsic clearance (1.2fold-3.75-fold); four subtypes $\left(2 \mathrm{C} 9^{\star} 27,{ }^{\star} 31,{ }^{\star} 41\right.$, and $\left.{ }^{\star} 56\right)$ exhibited no significant change on enzyme activity. The remaining 31 alleles expressed different degrees of reduction compared with wild type (Zheng et al., 2017).

Another in vitro study demonstrated that genetic variations in the CYP2B6 gene caused significant differences in plasma clearance of ketamine as well as in the ratio of norketamine: ketamine metabolic ratios. Specifically, those with the CYP2B $6^{\star} 6 /$ ${ }^{*} 6$ genotype exhibited a significantly lower plasma clearance of ketamine and norketamine: ketamine ratio when compared with both the CYP2B $66^{\star} 6 /{ }^{\star} 1$ and $\mathrm{CYP} 2 \mathrm{~B}^{\star} 1{ }^{\star} 1$ genotypes $(p<0.05)(\mathrm{Li}$ et al., 2013). 

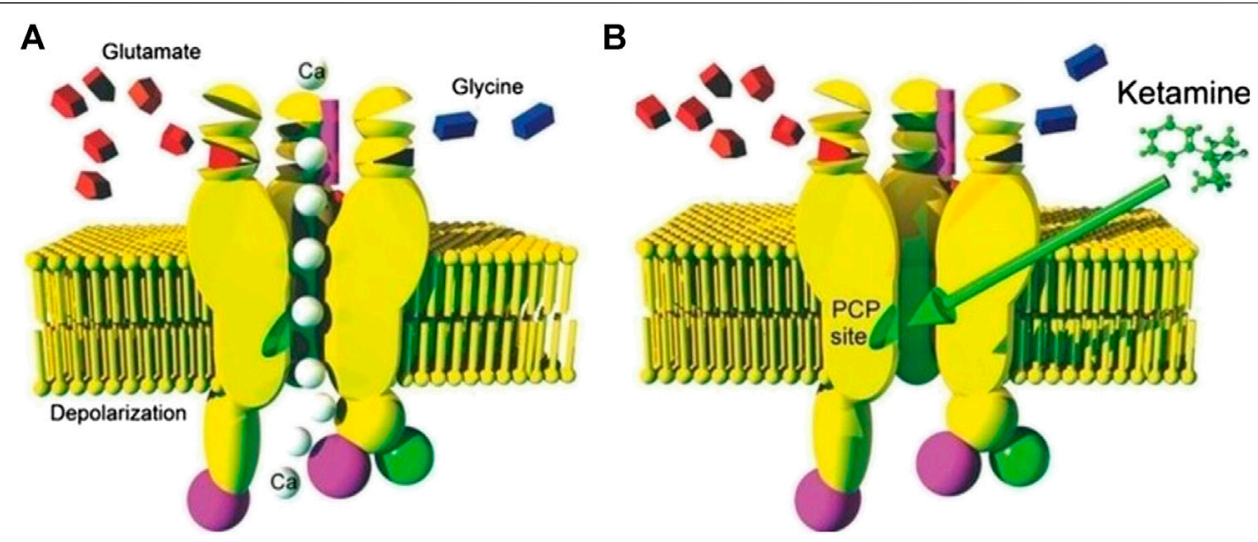

FIGURE 2 | (A) Depiction of an NMDA Receptor in the open state and allowing passage of calcium ions due to binding of glutamate and or/glycin (B) An image of an NMDA receptor blockaded by binding of ketamine due to binding of the drug at the PCP binding site Mion and Villevieille (2013).

With this information, CYP2B6 genotypes were identified in 49 chronic pain patients who received $24 \mathrm{~h}$ continuous subcutaneous infusions of ketamine. Steady-state plasma concentrations of ketamine and norketamine were determined using High Performance Liquid Chromatography (HPLC). Patients with the CYP2B6 $6^{\star} 6$ allele demonstrated a substantial decrease in steady-state ketamine plasma clearance (Li et al., 2015). This decreased ketamine clearance is clinically significant as it could potentially be associated with a higher incidence of ketamine-induced adverse events.

The importance of the CYP2B6 gene was confirmed by another study which demonstrated that per molecule the enzymatic activity of the CYP2B6 gene product was higher than that of CYP3A4 or CYP2C9 when comparing $\mathrm{N}$-demethylation of ketamine to norketamine. However, the same study demonstrated that when adjusted for the average relative content of these three enzymes in human hepatocytes CYP3A4 is the principle enzyme of ketamine metabolism at therapeutic concentrations due to is $\sim 30$-fold higher abundance (Hijazi \& Boulieu, 2002). Unfortunately, no research has yet been published on the effect of different CYP3A4 alleles on ketamine metabolism and clearance. This could be an area for ketamine pharmacogenomic research moving forward.

\section{MECHANISM OF ACTION}

\section{General Mechanism of Action}

Ketamine's mechanism of action is widely regarded as one of pharmacology's most complex due to its interaction with multiple binding sites including NMDA receptors, opioid receptors, $\mathrm{Na}$ channels, and L-type calcium channels (Kohrs and Durieux, 1998).

The primary anesthetic effect of ketamine is associated with NMDA receptor blockade which utilizes an uncompetitive mechanism with a relatively long knock-off time. Blockade of NMDA receptors disrupts normal excitatory glutamate signaling in the CNS and is associated with many anesthetic agents. A depiction of ketamine's action on the NMDA receptor can be seen in Figure 2 (Mion and Villevieille, 2013).

Besides NMDA receptors, ketamine also exhibits high affinity for the dopamine $\mathrm{D} 2$ and serotonin $5-\mathrm{HT}_{2}$ binding sites and significantly inhibits their uptake. Affinity of ketamine for the 5HT site is equal to that of ketamine for NMDA receptors. Affinity for the D2 site is $1 / 3$ rd of that (Kapur and Seeman, 2002). The fact that the binding affinities are similar to that of the NMDA receptor means significant binding of ketamine to D2 and 5$\mathrm{HT}_{2}$ receptors will occur at clinically relevant drug concentrations and may be responsible for some of ketamine's clinical effects. Indeed, 5-HT antagonists such as methysergide have been shown to antagonize ketamine's analgesic effect; indicating that serotonergic pathways are likely involved in ketamine analgesia (Crisp et al., 1991).

Ketamine has also been shown to bind to all types of opioid receptors with the highest affinity for mu receptors, followed by kappa, and finally delta receptors (Smith et al., 1998; Sleigh et al., 2014). While opioid receptors are often associated with analgesia, ketamine's interactions with these receptors are not believed to produce a significant analgesic effect. This is due to ketamine's affinity for the opioid receptors being at least tenfold less than for that of NMDA receptors (Smith et al., 1998). Additionally, ketamine's analgesia is not reversed by administration of mu opioid receptor agonists such as naloxone which suggests the mu receptor binding plays a minimal (if any) roll in ketamine analgesia (Bansinath et al., 1992).

Muscarinic receptors are antagonized by ketamine although with 10 to 20 fold less affinity than NMDA receptors. The inhibitory effect of ketamine on the muscarinic system is believed to play a role in some peripheral side effects of the drug such as increased sympathetic tone, pupillary dilation, and bronchodilation. It is also hypothesized that the anti-muscarinic effect of ketamine may be partly responsible for ketamineinduced amnesia as the muscarinic pathways have been demonstrated to play important roles in memory, consciousness, and learning (Durieux, 1995). 


\section{Inhibition of Astrocyte Activation}

One of the more recent uses of ketamine treatment has been in the targeted treatment of neuropathic pain. Ketamine is believed to inhibit the development and lessen the severity of neuropathic pain conditions by inhibiting the inflammatory signaling pathway of some glial cell types which is associated with development of pain states.

In mouse models astrocyte activation (as measured by increased GFAP) corresponded to development of neuropathic pain behavior. Meanwhile, administration of minocycline (microglial activation inhibitor) and pentoxifylline (cytokine release inhibitor) reduced CCI-related hypersensitivity (Mika et al., 2009). Likewise, activation of glial cells results in release of pro-inflammatory cytokines, similar to those seen with a spinal infection, that can be correlated with pathological pain (Watkins et al., 2001).

The increased use ketamine in neuropathic has been fueled by research indicating that ketamine may not only provide analgesia for these conditions but also stop the development and advancement of neuropathic pain at its source. For example, a mouse spinal nerve ligation (SNL) model demonstrated that ketamine administration inhibits astrocyte activation and down-regulates expression of GFAP protein (X. Mei et al., 2009).

Ketamine may also play a role in decreasing neuronal inflammation by inhibiting cytokine release as ketamine reduces LPS-induced TNF-a production in mixed glial cell cultures (Shibakawa et al., 2005).

Other models have shown that administration of S-ketamine entirely inhibited pharmacologically induced tactile allodynia via inhibition of Voltage-Gated Calcium Dependent (BK) Potassium Channels leading to decreased mIL-1B and BDNF secretion and reduced glial activation. Another known inhibitor of this channel, charybdotoxin, was shown to significantly reduce nerve injury induced tactile allodynia in mice (Hayashi et al., 2011).

\section{Ketamine and Opioid-Induced Hyperalgesia (OIH)}

While the exact mechanism of Opioid Induced Hyperalgesia $(\mathrm{OIH})$ is unknown, one of the leading theories is overactivation and stimulation of the NMDA-receptor. OIH is more commonly observed following high-dose opioid administration such as that used for refractory cancer pain. This proposed mechanism would explain why NMDA Receptor modulators such as ketamine are effective in treating the condition (Lee et al., 2011).

One study proving this efficacy demonstrated that compared to those who underwent anesthesia with high-dose remifentanil only, patients receiving high-dose remifentanil and intraoperative ketamine infusion experienced less post-operative hyperalgesia as measured by pain rating at 6 and $24 \mathrm{~h}$ and cumulative fentanyl dose before release (Choi et al., 2015). In another study, patients on a ketamine infusion of $2 \mathrm{mg} / \mathrm{kg} / \mathrm{min}$ following lumbar spinal fusion had significantly lower total fentanyl consumption than a $1 \mathrm{mg} / \mathrm{kg} / \mathrm{min}$ dose and control patients. The incidence of adverse events was not significantly different between groups (Kim et al., 2013).
Together, these studies indicate that ketamine may counteract $\mathrm{OIH}$ and thereby decreased total daily oral morphine equivalent required for pain management. Clinically, this information has been applied by using ketamine as an agent to reduce total opioid usage perioperatively, treat opioid induce neurotoxicity, and to control pain that has stopped responding to opioid escalation (Gharaei et al., 2013; Morley, 2003; Winegarden et al., 2016). Given the current opioid addiction epidemic and adverse event profile of opioids the potential for ketamine to reduce the magnitude of their use should be researched further.

\section{BASIC SCIENCE EVIDENCE OF KETAMINE EFFICACY}

\section{Chemotherapy-Induced Neuropathic Pain}

Due to the frequency of chemotherapy-induced neuropathic pain in cancer patients, an established animal model for this pain condition (paclitaxel-induced neuropathy) was used to determine the potential efficacy of ketamine. In two separate studies systemic ketamine injection ameliorated pain behaviors including mechanical allodynia and thermal hyperalgesia rats (Pascual et al., 2010; Hwang et al., 2012). Interestingly, one study found that a higher dose was required to significantly reduce pain thresholds in male rats when compared to their female counterparts (Hwang et al., 2012).

\section{Nerve-Injury-Induced Neuropathic Pain}

Nerve injury-induced neuropathic pain animal models include spinal nerve ligation (SNL), chronic constriction injury (CCI), spared nerve injury (SNI), constriction of the infraorbital nerve, and complete spinal cord transection in animals including rat and mouse.

The single systemic injection of ketamine reduced several nociceptive pain behaviors including mechanical allodynia and hyperalgesia, cold allodynia, spontaneous pain in SNL model in rat at dose of $0.01,1,5,10 \mathrm{mg} / \mathrm{kg}$. However, high doses $(25$, $50 \mathrm{mg} / \mathrm{kg}$ ) produced adverse effects including motor impairment (Qian et al., 1996; Suzuki et al., 2001). In addition, repeated systemic injection or systemic infusion of ketamine also reduced mechanical allodynia in SNL in rats at dose of 3,10 mg/kg daily or $40 \mathrm{mg} / \mathrm{kg} /$ day (Kwon et al., 2014; Schwenk et al., 2016). In the SNL model in rat, intrathecal injection of ketamine reduced mechanical allodynia at a dose of $10,30,100,300,1,000 \mu \mathrm{g} / \mathrm{kg}$, which means that the spinal cord was major site of action of ketamine (Burton et al., 1999; Cohen et al., 2009; Mei et al., 2010; Mei, et al., 2011a; Mei, et al., 2011b).

In the SNI model, repeated injection or systemic infusion of ketamine reduced mechanical and cold allodynia for several weeks at dose of $9 \mathrm{mg} / \mathrm{kg} /$ day for 5 days or $3 \mathrm{mg} / \mathrm{kg} / \mathrm{h}$ for $3 \mathrm{~h}$ daily, total for 5 days (Cohen et al., 2004; Swartjes et al., 2011). However, the single systemic injection did not produce analgesic effect at a dose of $10 \mathrm{mg} / \mathrm{kg}$ (Cohen et al., 2006).

In the CCI model, systemic injection of ketamine reduced heat hyperalgesia and mechanical allodynia for several hours at a dose of 30, 40, and 50 mg/kg (Vissers et al., 2006; Nina Dimitrova et al., 
2019). Its ED25 was $31.8 \mathrm{mg} / \mathrm{kg}$ by single subcutaneous injection (Pelissier et al., 2003).

\section{Diabetic Neuropathic Pain}

Another condition which frequently manifests with neuropathic pain is chronic diabetes. In mice, this can be modeled with highdose injection of streptozotocin which selectively kills pancreatic beta cells through DNA alkalization.

In two studies of streptozotocin-induced diabetic neuropathy, systemic infusion of ketamine at $20 \mathrm{mg} / \mathrm{kg} /$ day for 5 days reduced heat and mechanical hyperalgesia for several weeks following treatment (Mak et al., 2015; Claudino et al., 2018). In one of the studies, ketamine-treated mice also demonstrated some opioidsparing effects for up to 6 weeks with an increased sensitivity to acute nociceptive effects of morphine (Mak et al., 2015).

\section{Other Neuropathic Pain}

While three of the most common neuropathic pain conditions have been discussed above, there are a multitude more neuropathic pain models available in animals to test the efficacy of ketamine. In various models including arthritic pain, distal tibia fracture and casting, ischemia and reperfusion, and herpetic pain, the systemic injection of ketamine reduced pain behaviors (Ward and Standage, 2003; Sasaki et al., 2008; Tajerian et al., 2015; Zhou et al., 2018).

In the distal tibia fracture and casting in mouse, subcutaneous injections of ketamine $(2 \mathrm{mg} / \mathrm{kg} /$ day for 7 days starting week 7 after fracture) reduced allodynia for 4 weeks after its termination (Tajerian et al., 2015).

In the ischemia and reperfusion models in rat, intraperitoneal injection of ketamine $(100 \mathrm{mg} / \mathrm{kg})$ reduced mechanical and cold allodynia (Liman et al., 2015).

In herpetic pain model using inoculation of Herpes simplex virus type 1 on skin of the femur in female C57BL/6 J mice, intraperitoneal injection of ketamine $(50 \mathrm{mg} / \mathrm{kg})$ reduced allodynia on day 7 after inoculation (Sasaki et al., 2008).

The success of ketamine in treating such a wide array of neuropathic pain models is promising as it suggests that ketamine is acting to reverse/inhibit a process involved in the general development of neuropathic pain rather than a process which may be specific to a single animal model. A summary of all the discussed basic science and animal model evidence of ketamine's efficacy as an analgesic can be found in Table $\mathbf{1}$.

\section{Acute Pain}

The use of ketamine have been reported in various acute pain animal models including writhing, hot plate, formalin and tailflick test in mice and rats. In various models Ketamine was administered by systemic administrations (subcutaneous injection and intraperitoneal injection) or local administrations (intrathecal injection and local injection into paw).

Takahashi et al. reported that subcutaneous injection of ketamine $(15,30 \mathrm{mg} / \mathrm{kg})$ promoted dose-related analgesia in both the acetic acid-induced writhing and hot plate tests in mice. Analgesia was not affected by pretreatment with naloxone $(10 \mathrm{mg} / \mathrm{kg})$.

Hillhouse and Negus reported that intraperitoneal injection of ketamine $(1.0-10.0 \mathrm{mg} / \mathrm{kg})$ blocked lactic acid-stimulated stretching in rats but failed to block lactic acid-induced depression in rats. In addition, higher doses of ketamine $(10 \mathrm{mg} / \mathrm{kg})$ depressed behaviors including lactic acidstimulated stretching and lactic acid-induced depression.

Finck et al. showed that the subcutaneous injection of ketamine $(20,25,30 \mathrm{mg} / \mathrm{kg})$ reduced the number of writhes in the morphine pellet-implanted mice using the abdominal constriction test. On the other hand, ketamine was found to be much less effective as an analgesic agent in the morphine tolerant mice. The data indicated a possible cross-tolerance between morphine and ketamine.

Millan and Seguin reported that in the formalin-induced licking behavior by intraplantar injection of formalin in mice and intraperitoneal injection of ketamine blocked both the early and late phases. The doses of ketamine used were $6.0 \mathrm{mg} / \mathrm{kg}$ for early phase and $7.7 \mathrm{mg} / \mathrm{kg}$ for late phase.

Bulutcu et al. reported that intraperitoneal injection $(1,5$ or $10 \mathrm{mg} / \mathrm{kg})$ or intrathecal injection $(10,30$ or $60 \mathrm{mcg} / \mathrm{mouse})$ of ketamine produced dose-dependent antinociceptive effects in the acetic acid-induced writhing and formalin tests but not in the tailflick nor in hot-plate tests in mice.

Lastly, Sawynok and Reid reported that local pretreatment with 10-1,000 nmol ketamine via subcutaneous injection into the dorsal surface of the hind paw had no effect on phase 2 flinching behaviors and phase 2 biting/licking behaviors produced by both $1.5 \%$ and $5 \%$ formalin. In addition, ketamine produced no effect on phase 1 behaviors. In addition, systemic intraperitoneal injection of ketamine $(10,30,60 \mathrm{mg} / \mathrm{kg})$ generally had no effect on phase 1 and 2 flinching behaviors.

\section{CLINICAL EVIDENCE OF KETAMINE EFFICACY}

For much of the drug's lifespan ketamine has been used primarily as a dissociative anesthetic and a pediatric analgesic for acute pain in the emergency department. However, more recently there has been renewed interest in the drug for potential treatment of refractory pain, substance abuse, and treatment resistant depression. Indeed, both intranasal and oral ketamine have recently garnered FDA approval for the treatment of depression (Gautam et al., 2020).

While the latest Cochrane Review from 2017 found insufficient evidence to recommend Ketamine as an adjunctive therapy in cancer pain, significant clinical evidence is building that demonstrates ketamine as a potent analgesic with a limited adverse event profile (Bell et al., 2017).

\section{Intravenous Infusions for Chronic Pain}

One of the first applications of ketamine for analgesia was via intravenous infusion due to the ability to avoid first-pass metabolism and the well-controlled nature of administration. Additionally, these infusions typically occurred in inpatient settings allowing the healthcare team to monitor for adverse conditions and track treatment efficacy.

A meta-analysis including a total of 211 patients in seven different studies revealed a significant analgesic effect for 
intravenous ketamine infusions in both neuropathic and nonneuropathic pain conditions when compared to placebo. The average infusion duration for these patients was $5 \mathrm{~h}$ reaching a median ketamine dose of $0.35 \mathrm{mg} / \mathrm{kg}$. In all seven studies, maximum analgesic effect was observed between $48 \mathrm{~h}$ and 2 weeks post-infusion. Magnitude of pain reduction remained significant until 4 weeks post-infusion with some effect seen as far as 8 weeks out. Efficacy of ketamine was not significantly different between pain conditions or classifications. The studies also reported no efficacy difference between ketamine as a standalone or adjuvant therapy. In all seven studies, maximum analgesic effect was observed between $48 \mathrm{~h}$ and 2 weeks (Orhurhu et al., 2019).

Taking the above meta-analysis into consideration, ketamine shows significant promise for the treatment of a wide variety of chronic pain conditions, including neuropathic and nonneuropathic. Furthermore, due to the long-acting nature of ketamine's analgesia this treatment can be offered outpatient with visits to pain management only required as frequently as infusions are needed.

Case studies also support the use of ketamine as a third-line agent in intractable cancer pain. In 12 cancer patients with intractable pain, ketamine infusions at a rate of $1.5 \mathrm{mg} / \mathrm{kg} / \mathrm{day}$ reduced total daily morphine use by $50 \%$ after patients were sent home with ketamine/morphine pain pumps. Side effects were minimal and only occurred with the initial testing dose (Lossignol et al., 2005).

\section{Oral and Nasal Ketamine for Chronic Pain}

In contrast to infusions of ketamine, oral and nasal formulations are commonly administered without direct physician supervision and are therefore more desirable for management of long-term pain conditions. While they require significantly higher doses due to extensive metabolism, oral administrations have also proven effective in providing analgesia.

Two studies investigating oral ketamine analgesia both showed at least mild pain reduction. One study with a daily dose of $2 \mathrm{mg} / \mathrm{kg}$ ketamine reduced or abolished pain in two-thirds of patients while one-half of patients reported some adverse event. Only half of these patients decided to stop the ketamine therapy. Interestingly, the incidence of adverse events was lower in patients concomitantly taking opioids (Marchetti et al., 2014). The second study also demonstrated significant pain score reduction with the most frequent adverse event reported being increased drowsiness (Kannan et al., 2002).

In addition to reduction of pain, oral ketamine has also shown promise in countering Opioid-induced Hyperalgesia (OIH). Patients administered oral ketamine $(0.5 \mathrm{mg} / \mathrm{kg}$ every $12 \mathrm{~h})$ had significantly lower oral morphine consumption than those in a control group. Indicating that ketamine has some analgesic and opioid tolerance sparing ability. Additionally, the ketamine patients reported decreased somnolence perhaps due to the decreased opioid dosing (Lauretti et al., 1999).

Intranasal administration of ketamine, although now more associated with treatment of depression, has also been tried for treatment of cancer pain. After treatment with intranasal ketamine using a nasal spray pump, $65 \%$ of breakthrough cancer pain patients achieved a Numerical Pain Intensity Scale (NPIS) score that was at least $40 \%$ lower than pre-treatment levels compared to $20 \%$ of placebo patients achieving the same metric ( $p=0.007$ ) (Carr et al., 2004). Other studies of intranasal ketamine are scarce, however with the emergence of FDA approved intra-nasal ketamine solutions for other conditions it is possible that more studies will be undertaken in this area.

\section{Ketamine as a Topical Agent}

For patients in whom systemic ketamine administration via oral or IV routes is not desirable administration of the drug as a topical agent may be possible. As with many drugs, this route provides the benefit of keeping plasma concentrations and therefore potential side effects at a minimum.

It is important to note that In addition to the central nervous system, NMDA receptors are widely present in the axons of the peripheral nervous system. In neuropathic and inflammatory pain conditions, topical ketamine alleviates pain by down regulating the upregulated NMDA, AMPA and kinate receptors (Coggeshall and Carlton 1998; Carlton, 2009).

One of the most frequent disorders that is treated with a ketamine topical is Chronic Regional Pain Syndrome (CRPS), a type of chronic neuropathic pain. Ketamine creams, both a $10 \%$ Ketamine only and a combination of ketamine and several other analgesics have been shown effective in reducing pain measures, tactile allodynia and Visual Analog Scale (VAS) pain score, in these patients in as little as $30 \mathrm{~min}$ and in a fraction of patients similar to systemic treatment (Heir et al., 2008; Finch et al., 2009). These studies also demonstrated that systemic levels of ketamine remain undetectable (Finch et al., 2009).

Others have also demonstrated that topical ketamine and amitriptyline cream is effective in other pain conditions such as postherpetic neuralgia (Lynch et al., 2005; Everton et al., 2007).

While these studies are promising, there are also several studies that seem to contradict their results. Many of the same topical applications mentioned above have been tested and shown no effect in other studies (de Barros et al., 2012; Gewandter et al., 2014; Lynch et al., 2003, Lynch et al., 2005). However, these studies did confirm that the adverse event profile of topical ketamine is minimal. Therefore, while the evidence for topical ketamine is not as strong as other routes of administration it may still be worth trying for some patients due to low risk. A tabulated form of the clinical evidence discussed throughout the preceding sections can be found in Table 2 .

\section{Ketamine in the Pediatric Population}

Documented use of ketamine for analgesia in the pediatric population is scarcer, the instances which we do have are promising. Ketamine therapy has been shown effective in a variety of pain conditions in the pediatric population and with a minimal adverse event profile similar to its general population use. Initial animal studies raised concern regarding the toxicity of ketamine to developing neuronal cells. However, these worries have been lessened as more recent studies have demonstrated that the developmental stage at which these animal studies took place correlates to a pre-birth period in humans. 
A case study of 12 children treated $3 x$ daily with oral ketamine demonstrated results similar to those in adults. Five of the 12 patients experienced significant improvement in pain scores that lasted up to four weeks after the ketamine treatment. Two patients eventually treated at the highest dose of $1.5 \mathrm{mg} / \mathrm{kg} /$ dose experienced dose-limiting toxicities and ceased treatment (Bredlau et al., 2013).

In another case study of 11 children ranging in age from 3-17 years old with inadequate pain control despite opioid escalation $73 \%$ of patients reported subjectively improved pain scores and total opioid consumption was decreased by $28 \%-100 \%$. These patients were receiving lorazepam concurrently to prevent psychiatric side effects (Finkel et al., 2007).

Likewise, a 13 year-old patient with refractory pain following pancreatitis was treated with hydromorphone until reaching a total daily morphine equivalent of $1,375 \mathrm{mg}$ and being admitted to the ICU. Following a sub-anesthetic administration of IV ketamine average 5 days pain score was rapidly reduced from 8.3 to 4.4 while OME requirements were reduced to $375 \mathrm{mg}$. The patient experienced no adverse effects from the drug (Mulder et al., 2018).

Finally, a single case report detailing a 14 year old patient with pain refractory to other treatments was admitted to the PICU and administered an infusion of ketamine at $7 \mu \mathrm{g} / \mathrm{kg} /$ minute for $24 \mathrm{~h}$ a day. Not only did this patient report a $70 \%$ decrease in total pain score, but also a decrease in depressive symptoms. Due to the success of this treatment, the patient was retreated in the same manner when presenting again 5-months later (Weber et al., 2018). The mitigation of depressive symptoms in pain conditions could potential serve as a niche application for ketamine in the future. Clinical evidence supporting the use of ketamine as an analgesic specifically relating to the pediatric population can be found in Table 3.

\section{Contraindications}

While ketamine is regarded as safe for the general population, the drug may be contraindicated or at least require special precautions for some sub-populations. The first of these is in patients who have a history of schizophrenia, psychotic symptoms, or Post-Traumatic Stress Disorder (PTSD). Ketamine has been shown to exacerbate and/or elicit psychotic symptoms in these patients and its use is therefore non-desirable (Lahti et al., 2001; Xu et al., 2015). When used in this population, strong consideration should be given to the use of benzodiazepines to help prevent development of psychotic symptoms (Krystal et al., 1999; Sinner and Graf, 2008).

Another population that may require special caution is patients with cardiovascular or hepatic compromise. Ketamine has been shown to produce increased cardiac stimulation which may be harmful to patients with previous cardiovascular disease (Dahan et al., 2009). Likewise, ketamine is known to be hepatotoxic, especially with chronic use, and exhibits a rise in liver function tests (LFTs) in up to $80 \%$ of patients (Kiefer et al., 2008).

Finally, ketamine is widely considered as contraindicated in patients less than 3 months of age due to complications in maintaining a patent airway (Dolansky et al., 2008). While some may consider this contraindication to extend out to 12 months of age, however there is evidence of use in this population with no adverse events (Green and Krauss, 2004).

\section{Summary of Clinical Evidence}

The above studies provide significant evidence that ketamine can be safely utilized for its analgesic properties in sub-anesthetic doses. Intravenous and oral/intranasal ketamine proved effective in a wide range of pain conditions including neuropathic pain, CRPS, and acute pain exacerbations. While hypothesized that ketamine may provide special benefits in neuropathic pain, the studies which explicitly examined this found no difference in efficacy based on pain condition. The dosages which provided effective analgesia were also consistent across pain conditions with most studies finding an i. v. infusion of $0.35 \mathrm{mg} / \mathrm{kg}$ ketamine effective for analgesia for up to two weeks. For oral ketamine, a daily dose around $1-1.5 / \mathrm{kg}$ mg seemed to be the standard and produced effects in $>50 \%$ of patients.

Topical ketamine has much less supporting evidence for its use but several reports detail efficacy in CRPS with minimal systemic absorption and adverse events.

The average dosage required for anesthesia in patients is $2 \mathrm{mg} / \mathrm{kg}$ as a single bolus over $1 \mathrm{~min}$ with anesthesia only lasting 5-10 min (White and Kershaw, 2015). Of the i. v. studies referenced the dose nearest to this is a $0.35 \mathrm{mg} / \mathrm{kg}$ infusion over $1 \mathrm{~h}$. If normalized to a 1 -min bolus, this would equate to less than $0.006 \mathrm{mg} / \mathrm{kg} / \mathrm{min}$ infusion rate which is clearly well below that required for anesthesia. The difference in the dosages providing analgesia and anesthesia provide a rather large therapeutic window, especially if the analgesic dose can be spread over time.

This therapeutic window is also confirmed for oral ketamine by plasma studies which demonstrate that analgesia is obtained at ketamine concentrations of $0.04 \mu \mathrm{g} / \mathrm{ml}$ when taken orally while anesthetic effects are not observed till a range of $0.64-1.12 \mu \mathrm{g} / \mathrm{ml}$ (White and Kershaw, 2015).

\section{ADVERSE EFFECTS AND ADDICTION}

Sub-anesthetic ketamine infusions were associated with adverse drug events (hallucination, dysphoria, dizziness, visual disturbance, or sedation) in $29.5 \%$ of patients. This occurrence rate was significantly lower $(10.3 \%$ vs. $37.3 \%)$ in patients diagnosed with depression. The researcher's hypothesis is that increased NMDA-receptor activity seen in depression is protective against psychotic effects of ketamine (Stoker et al., 2019).

\section{Ketamine Cognitive Effects}

Ketamine has long been known to have cognitive side effects that frequently limit its use. In fact, ketamine was known to produce dissociative and psychomimetic effects within years of its discovery (Domino et al., 1965). These cognitive effects are also responsible for the continued abuse of ketamine as a street drug. 
TABLE 1 | Animal studies using ketamine for chronic pain.

\begin{tabular}{|c|c|c|c|}
\hline Authors & Animal model & Ketamine treatment & Results \\
\hline \multicolumn{4}{|c|}{ Chemotherapy-induced neuropathic pain } \\
\hline $\begin{array}{l}\text { Hwang et al. } \\
\text { (2012) }\end{array}$ & $\begin{array}{l}\text { Paclitaxel-induced } \\
\text { neuropathic pain in rats }\end{array}$ & Intraperitoneal injection of 2 or $5 \mathrm{mg} / \mathrm{kg}$ ketamine & $\begin{array}{l}\text { The lower dose of } 2 \mathrm{mg} / \mathrm{kg} \text { only reduced mechanical } \\
\text { allodynia in male rats. The } 5 \mathrm{mg} / \mathrm{kg} \text { dose reduced } \\
\text { mechanical allodynia in both male and female rats }\end{array}$ \\
\hline $\begin{array}{l}\text { Pascual et al. } \\
\text { (2010) }\end{array}$ & $\begin{array}{l}\text { Paclitaxel-induced } \\
\text { neuropathic pain in rat }\end{array}$ & Intraperitoneal injection of ketamine (maximum 50 mg/kg) & $\begin{array}{l}\text { Only the highest dose of ketamine }(50 \mathrm{mg} / \mathrm{kg}) \text { reduced } \\
\text { the mechanical allodynia and thermal hyperalgesia induce } \\
\text { by paclitaxel }\end{array}$ \\
\hline \multicolumn{4}{|c|}{ Nerve injury-induced neuropathic pain } \\
\hline $\begin{array}{l}\text { Schwenk et al. } \\
\text { (2016) }\end{array}$ & Spinal nerve ligation in rats & $\begin{array}{l}\text { Intraperitoneal injection of } 3 \text { or } 10 \mathrm{mg} / \mathrm{kg} \text { ketamine daily for } \\
4 \text { weeks }\end{array}$ & $\begin{array}{l}\text { Ketamine increased mechanical pain thresholds during } \\
\text { weeks } 2-4\end{array}$ \\
\hline $\begin{array}{l}\text { Qian et al. } \\
\text { (1996) }\end{array}$ & Spinal nerve ligation in rats & $\begin{array}{l}\text { Intraperitoneal injection of } 0.01 .1,25 \text {, or } 50 \mathrm{mg} / \mathrm{kg} \\
\text { ketamine }\end{array}$ & $\begin{array}{l}\text { Ketamine injection up to } 1 \mathrm{mg} / \mathrm{kg} \text { reduced nociceptive } \\
\text { behaviors for a minimum of } 15 \mathrm{~min} \text { with the higher doses } \\
\text { providing longer relief up to } 75 \mathrm{~min} \text { without noticeable } \\
\text { side effects. The two highest doses ( } 25 \text { and } 50 \mathrm{mg} / \mathrm{kg} \text { ) } \\
\text { provided even longer relief but induced transient motor } \\
\text { impairment }\end{array}$ \\
\hline $\begin{array}{l}\text { Suzuki et al. } \\
\text { (2001) }\end{array}$ & Spinal nerve ligation in rats & Intravenous injection of $1,5,10 \mathrm{mg} / \mathrm{kg}$ ketamine & $\begin{array}{l}\text { Ketamine produced a greater decrease in the noxious } \\
\text { and innocuous mechanical evoked responses when } \\
\text { compared to MK- } 801 \text { and memantine }\end{array}$ \\
\hline $\begin{array}{l}\text { Kwon et al. } \\
(2014)\end{array}$ & Spinal nerve ligation in rats & $\begin{array}{l}\text { Subcutaneous infusion of } 40 \mathrm{mg} / \mathrm{kg} / \text { day ketamine for } \\
7 \text { days }\end{array}$ & $\begin{array}{l}\text { Ketamine reduced mechanical allodynia after } 3 \text { days of } \\
\text { infusions }\end{array}$ \\
\hline $\begin{array}{l}\text { Mei, et al. } \\
\text { (2011a) }\end{array}$ & Spinal nerve ligation in rats & Intrathecal injection of $30,100,300 \mu \mathrm{g} / \mathrm{kg}$ ketamine & $\begin{array}{l}\text { Ketamine reduced mechanical allodynia in a dose- } \\
\text { dependent manner }\end{array}$ \\
\hline $\begin{array}{l}\text { Mei, et al. } \\
\text { (2011b) }\end{array}$ & Spinal nerve ligation in rats & $\begin{array}{l}\text { Intrathecal injection of } 100,300 \mu \mathrm{g} / \mathrm{kg} / \text { day ketamine for } \\
2 \text { days }\end{array}$ & $\begin{array}{l}\text { Ketamine reduced mechanical allodynia without } \\
\text { interfering with motor performance }\end{array}$ \\
\hline Mei et al. (2010) & Spinal nerve ligation in rats & Intrathecal injection of $10,100,1,000 \mu \mathrm{g} / \mathrm{kg}$ ketamine & $\begin{array}{l}\text { Ketamine reduced mechanical allodynia in a dose- } \\
\text { dependent manner }\end{array}$ \\
\hline $\begin{array}{l}\text { Burton et al. } \\
\text { (1999) }\end{array}$ & Spinal nerve ligation in rats & $\begin{array}{l}\text { Intrathecal injection of } 1 \mathrm{mg} / \mathrm{kg} \text { ketamine at } 15 \mathrm{~min} \text { before } \\
\text { injury }\end{array}$ & $\begin{array}{l}\text { Ketamine reduced mechanical allodynia, cold allodynia, } \\
\text { and ongoing pain as revealed by the von frey hair, } \\
\text { acetone, and cold plate testing, respectively. This } \\
\text { decrease in allodynia was maintained for at least } 2 \text { weeks }\end{array}$ \\
\hline $\begin{array}{l}\text { Cohen et al. } \\
\text { (2009) }\end{array}$ & Spinal nerve ligation in rats & Intrathecal injection of $1 \mathrm{mg} / \mathrm{kg}$ ketamine & $\begin{array}{l}\text { Ketamine reduced mechanical and cold allodynia for } \\
2 \text { weeks }\end{array}$ \\
\hline $\begin{array}{l}\text { Wang et al. } \\
\text { (2011) }\end{array}$ & Spared nerve injury in rats & Intraperitoneal injection of $10 \mathrm{mg} / \mathrm{kg}$ ketamine & $\begin{array}{l}\text { The single injection of ketamine did not alter spared nerve } \\
\text { injury-induced hypersensitivity. However, it did reduce } \\
\text { spared nerve injury-associated depression-like behaviors }\end{array}$ \\
\hline $\begin{array}{l}\text { Cohen et al. } \\
\text { (2006) }\end{array}$ & Spared nerve injury in rats & Intraperitoneal injection of $10 \mathrm{mg} / \mathrm{kg}$ ketamine & Ketamine did produce significant analgesic effects \\
\hline $\begin{array}{l}\text { Swartjes et al. } \\
\text { (2011) }\end{array}$ & Spared nerve injury in rats & $\begin{array}{l}\text { Intravenous infusions of } 3 \mathrm{mg} / \mathrm{kg} / \text { hour ketamine for } 3 \mathrm{~h} \text { for } \\
5 \text { consecutive days ( } 9 \mathrm{mg} / \mathrm{kg} / \text { day for } 5 \text { days) }\end{array}$ & $\begin{array}{l}\text { Ketamine infusion reduced mechanical allodynia with } \\
\text { maximum relief occurring at postoperative week } 2\end{array}$ \\
\hline $\begin{array}{l}\text { Cohen et al. } \\
(2004)\end{array}$ & Spared nerve injury in rats & $\begin{array}{l}\text { Intravenous infusion of } 3 \mathrm{mg} / \mathrm{kg} / \mathrm{h} \text { for } 3 \mathrm{~h} \text { daily for five } \\
\text { consecutive days ( } 9 \mathrm{mg} / \mathrm{kg} / \text { day for } 5 \text { days) }\end{array}$ & $\begin{array}{l}\text { Ketamine decreased mechanical and cold allodynia for } \\
\text { 3-6 weeks after the first injection }\end{array}$ \\
\hline $\begin{array}{l}\text { Vega-Avelaira } \\
\text { et al. (2012) }\end{array}$ & Spared nerve injury in rats & Subcutaneous injection of 1,10 , or $20 \mathrm{mg} / \mathrm{kg}$ ketamine & $\begin{array}{l}\text { Ketamine reduced mechanical nociceptive thresholds. At } \\
\text { the highest }(20 \mathrm{mg} / \mathrm{kg}) \text { dose the threshold was returned } \\
\text { to control levels }\end{array}$ \\
\hline ND et al. (2019) & $\begin{array}{l}\text { Chronic constriction injury in } \\
\text { rats }\end{array}$ & Intraperitoneal injection of 30,40 , or $50 \mathrm{mg} / \mathrm{kg}$ ketamine & $\begin{array}{l}\text { Ketamine reduced heat hyperalgesia at } 2 \text { and } 3 \mathrm{~h} \text { after } \\
\text { injection and reduced mechanical allodynia at } 1 \mathrm{~h} \text { after } \\
\text { injection }\end{array}$ \\
\hline $\begin{array}{l}\text { Vissers et al. } \\
\text { (2006) }\end{array}$ & $\begin{array}{l}\text { Chronic constriction injury in } \\
\text { rats }\end{array}$ & Intraperitoneal injection of 40 mg/kg ketamine & Ketamine reduced cold allodynia at $1 \mathrm{~h}$ \\
\hline $\begin{array}{l}\text { Christoph et al. } \\
\text { (2006) }\end{array}$ & $\begin{array}{l}\text { Chronic constriction injury in } \\
\text { rats }\end{array}$ & Intravenous injection of $4.64 \mathrm{mg} / \mathrm{kg}$ ketamine & $\begin{array}{l}\text { Ketamine }(4.64 \mathrm{mg} / \mathrm{kg}) \text { reduced cold allodynia for more } \\
\text { than } 3 \mathrm{~h}\end{array}$ \\
\hline $\begin{array}{l}\text { Pelissier et al. } \\
\text { (2003) }\end{array}$ & $\begin{array}{l}\text { Chronic constriction injury in } \\
\text { rats }\end{array}$ & $\begin{array}{l}\text { Subcutaneous injection of } 12.5,25,50 \text {, or } 100 \mathrm{mg} / \mathrm{kg} \\
\text { ketamine }\end{array}$ & $\begin{array}{l}\text { The ED25 and the } 95 \% \text { confidence limit (in parentheses) } \\
\text { of ketamine were } 31.8(23.9-42.2) \mathrm{mg} / \mathrm{kg}\end{array}$ \\
\hline Lim et al. (2013) & $\begin{array}{l}\text { Chronic constriction injury in } \\
\text { mice }\end{array}$ & Intrathecal injection of $3,10,30$, or $100 \mu g$ ketamine & $\begin{array}{l}\text { The } 3 \text { and } 10 \mu g \text { dose of ketamine was not effective on } \\
\text { neuropathic pain while the } 30 \text { and } 100 \mu g \text { showed } \\
\text { significant analgesia }\end{array}$ \\
\hline $\begin{array}{l}\text { Claudino et al. } \\
\text { (2018) }\end{array}$ & $\begin{array}{l}\text { Constriction of the infraorbital } \\
\text { nerve in rats }\end{array}$ & Intranasal administration of 0.5 or $1 \mathrm{mg} / \mathrm{kg}$ ketamine & $\begin{array}{l}\text { Intranasal ketamine at } 0.5 \mathrm{mg} / \mathrm{kg} \text { reduced the heat } \\
\text { hyperalgesia } 4 \text { days post-injury and at } 1 \mathrm{mg} / \mathrm{kg} \\
\text { attenuated the mechanical hyperalgesia at } 14 \text { days post- } \\
\text { injury }\end{array}$ \\
\hline Staff (2015) & $\begin{array}{l}\text { Complete spinal cord } \\
\text { transection in rats }\end{array}$ & Intraperitoneal injection of $50 \mathrm{mg} / \mathrm{kg}$ ketamine & $\begin{array}{l}\text { Acute treatment with ketamine reduced mechanical } \\
\text { allodynia for } 1 \mathrm{~h}\end{array}$ \\
\hline
\end{tabular}


TABLE 1 | (Continued) Animal studies using ketamine for chronic pain.

\begin{tabular}{|c|c|c|c|}
\hline Authors & Animal model & Ketamine treatment & Results \\
\hline \multicolumn{4}{|c|}{ Diabetic neuropathic pain } \\
\hline $\begin{array}{l}\text { Mak et al. } \\
\text { (2015) }\end{array}$ & $\begin{array}{l}\text { Streptozotocin-induced } \\
\text { diabetic neuropathy in rats }\end{array}$ & $\begin{array}{l}\text { Subcutaneous infusion of } 1 \text { ) ketamine } 20 \mathrm{mg} / \mathrm{kg} / \text { day + } \\
\text { morphine } 20 \mathrm{mg} / \mathrm{kg} / \text { day for } 5 \text { days, 2) ketamine } 20 \mathrm{mg} / \\
\mathrm{kg} / \text { day for } 5 \text { days }\end{array}$ & $\begin{array}{l}\text { Each treatment of 1) and 2) reduced heat hyperalgesia for } \\
12 \text { and } 4 \text { weeks, respectively. The ketamine-treated rats } \\
\text { also demonstrated opioid-sparing effects }\end{array}$ \\
\hline $\begin{array}{l}\text { Claudino et al. } \\
\text { (2018) }\end{array}$ & $\begin{array}{l}\text { Streptozotocin-induced } \\
\text { diabetic neuropathy in rats }\end{array}$ & $\begin{array}{l}\text { Subcutaneous infusion of } 20 \mathrm{mg} / \mathrm{kg} / \text { day ketamine for } \\
5 \text { days }\end{array}$ & $\begin{array}{l}\text { The 5-days ketamine infusion showed anti-hyperalgesia } \\
\text { for up to } 4 \text { weeks post-treatment }\end{array}$ \\
\hline \multicolumn{4}{|c|}{ Other neuropathic pain } \\
\hline $\begin{array}{l}\text { Zhou et al. } \\
\text { (2018) }\end{array}$ & $\begin{array}{l}\text { Complete Freund's adjuvant } \\
\text { injection in rats }\end{array}$ & $\begin{array}{l}\text { Intraperitoneal injection of } 10 \mathrm{mg} / \mathrm{kg} \text { and then } 20 \mathrm{mg} / \mathrm{kg} \\
\text { for } 8 \text { days }\end{array}$ & $\begin{array}{l}\text { Ketamine reduced aversive effects on day } 2 \text { after the first } \\
\text { ketamine injection }\end{array}$ \\
\hline $\begin{array}{l}\text { Ward and } \\
\text { Standage (2003) }\end{array}$ & Arthritic pain in rat by CFA & $\begin{array}{l}\text { Subcutaneous injection of 2, } 10 \text { mg/kg ketamine x20 } \\
\text { doses in } 4 \text { weeks }\end{array}$ & $\begin{array}{l}\text { Ketamine reduced arthritic pain starting on week } 2 \text { for } \\
10 \mathrm{mg} / \mathrm{kg} \text { dosing and week } 3 \text { for } 2 \mathrm{mg} / \mathrm{kg} \text { dosing }\end{array}$ \\
\hline $\begin{array}{l}\text { Tajerian et al. } \\
\text { (2015) }\end{array}$ & $\begin{array}{l}\text { Distal tibia fracture and } \\
\text { casting in mouse }\end{array}$ & $\begin{array}{l}\text { Subcutaneous injection of } 2 \mathrm{mg} / \mathrm{kg} / \text { day ketamine for } 7 \\
\text { days starting week } 7 \text { after fracture }\end{array}$ & $\begin{array}{l}\text { Ketamine reduced allodynia for } 4 \text { weeks after termination } \\
\text { of ketamine }\end{array}$ \\
\hline $\begin{array}{l}\text { Liman et al. } \\
\text { (2015) }\end{array}$ & $\begin{array}{l}\text { Ischemia and reperfusion in } \\
\text { rats }\end{array}$ & Intraperitoneal injection of $100 \mathrm{mg} / \mathrm{kg}$ ketamine & Ketamine reduced mechanical and cold allodynia \\
\hline $\begin{array}{l}\text { Sasaki et al. } \\
\text { (2008) }\end{array}$ & $\begin{array}{l}\text { Inoculation of herpes simplex } \\
\text { virus type } 1\end{array}$ & Intraperitoneal injection of $50 \mathrm{mg} / \mathrm{kg}$ ketamine & Ketamine reduced allodynia on day 7 after inoculation \\
\hline
\end{tabular}

One of the most prominent cognitive side effects is the sense of a general "euphoria" and disconnection from their surroundings. In a study of healthy volunteers, ketamine administration produced a discernible change in subjective experience in patients including prominence of distant sounds, feelings of dreaminess, loss of attentiveness, and illusory perception of movements. With an oral dose of $25 \mathrm{mg}$ of ketamine, all patients were able to distinguish a feeling of dreaminess/less attentiveness compared to a when receiving a placebo (Harborne et al., 1996).

In addition to these euphoric feelings, ketamine has also been shown to produce a formal thought disorder and impairments in both working and semantic memory function in healthy volunteers (Adler et al., 1998). In chronic ketamine abusers, these memory impairments have been shown to persist even after abstinence from ketamine suggesting permanent damage to the brain (Niesters et al., 2014).

While the exact mechanism of these cognitive effects is unknown, ketamine has been shown to produce both structural and physiological changes in the brain. One study shows that ketamine produced a focal increase in metabolic activity in the pre-frontal cortex that was associated with development of an acute psychotic state (Breier et al., 1997). Meanwhile in a series of two studies Lia et al. showed decreased gray and white matter volumes in the pre-frontal cortex and white matter degeneration in the left temporoparietal lobe (Liao et al., 2010; Liao et al., 2011).

Regardless of mechanism, the occurrence of these well-documented cognitive events has generated research into what psychiatric drugs may be able to prevent them and therefore allow wider use of ketamine. Several of these studies have demonstrated that benzodiazepines, specifically midazolam and haloperidol, reduced undesired psychotic side-effects and nausea associated with ketamine administration (Mathisen et al., 1995; Mercadante et al., 1995).

\section{Ketamine Cystitis}

Due to a high occurrence in chronic ketamine abusers, ketamine cystitis is also a concern when discussing long-term use of ketamine as analgesia. Urinary tract symptoms indicative of cystitis are reported in over $25 \%$ of long-term ketamine abusers with occurrence related in a dose and frequency dependent manner. Also of importance is that only $51 \%$ of respondents reported improvement in symptoms following cessation of ketamine (Winstock et al., 2012).

The chronic inflammation of the bladder and urinary tract in ketamine cystitis may be due to abnormal increases in neurotrophin seen in bladder tissue exposed to ketamine. Rats taking ketamine have also been observed to have increased expression of iNOS and COX enzymes within bladder tissue. The only conclusive treatment for ketamine cystitis is cessation of the drug although, as mentioned above, some patients with irreversible damage such as thickened bladder walls and hydronephrosis may have symptoms persist and require surgical intervention (J.-F. Jhang et al., 2015).

One unique aspect of ketamine-related cystitis is a significant elevation in serum IgE levels when compared to control patients and those with an acute bacterial cystitis. This elevated IgE was also significantly correlated with pain severity and decreased total bladder capacity (J. F. Jhang et al., 2014). Perhaps this IgE elevation could be a potential therapeutic target for the prevention of ketamine cystitis or even a biomarker for its potential onset.

\section{Ketamine Hepatotoxicity}

Patients administered ketamine infusions for treatment of CRPS showed signs and symptoms of drug-induced liver injury as evidenced by elevated serum AST, ALT, and gamma-glutamyl transferase levels. Frequency of this druginduced hepatotoxicity caused the authors to end their proposed study earlier than anticipated (Noppers et al., 2011).

Sixteen of twenty (80\%) of CRPS patients treated with ketamine infusions for refractory pain experienced transient elevations in lever enzyme (AST, ALT, GGT) levels that decreased back to baseline within 10-14 days following treatment (Kiefer et al., 2008). 
TABLE 2 | Compiled clinical evidence supporting ketamine's analgesic effects.

\begin{tabular}{|c|c|c|c|c|c|c|}
\hline Authors & Pain condition & Study type & Ketamine treatment & $\begin{array}{c}\text { Sample } \\
\text { size }\end{array}$ & Results & Comments \\
\hline
\end{tabular}

\begin{tabular}{|c|c|c|c|c|c|}
\hline \multicolumn{6}{|c|}{ Intravenous ketamine infusion } \\
\hline $\begin{array}{l}\text { Schwartzman } \\
\text { et al. (2009) }\end{array}$ & $\begin{array}{l}\text { Chronic regional } \\
\text { pain syndrome } \\
\text { (CRPS) }\end{array}$ & $\begin{array}{l}\text { Double-blind } \\
\text { placebo } \\
\text { controlled }\end{array}$ & $\begin{array}{l}\text { Maximum of } 0.35 \mathrm{mg} / \mathrm{kg} / \mathrm{h} \times \\
4 \mathrm{hr} \times 10 \text { days }\end{array}$ & 19 & $\begin{array}{l}\text { Intravenously ketamine } \\
\text { administered via outpatient } \\
\text { setting significantly reduced } \\
\text { several pain parameters }\end{array}$ \\
\hline $\begin{array}{l}\text { Orhurhu et al. } \\
\text { (2019) }\end{array}$ & $\begin{array}{l}\text { Mixed neuropathic } \\
\text { and non- } \\
\text { neuropathic }\end{array}$ & $\begin{array}{l}\text { Meta- } \\
\text { analysis }\end{array}$ & $\begin{array}{l}\text { Varies, median } 0.35 \mathrm{mg} / \mathrm{kg} / \mathrm{h} \\
\text { for } 5 \mathrm{~h}\end{array}$ & 211 & $\begin{array}{l}\text { Ketamine has significant } \\
\text { analgesic benefit up to } 2 \text { weeks } \\
\text { after cessation of } \\
\text { administration. High-dose } \\
\text { ketamine significantly more } \\
\text { effective than low-dose }\end{array}$ \\
\hline $\begin{array}{l}\text { Lossignol } \\
\text { et al. (2005) }\end{array}$ & $\begin{array}{l}\text { Intractable cancer } \\
\text { pain }\end{array}$ & Case series & 1.5 mg/kg/day ketamine & 12 & $\begin{array}{l}\text { Ketamine infusion improved } \\
\text { pain controlled and reduced } \\
\text { total daily morphine use by an } \\
\text { average of } 50 \%\end{array}$ \\
\hline $\begin{array}{l}\text { Lauretti et al. } \\
\text { (1999) }\end{array}$ & Cancer pain & $\begin{array}{l}\text { Multi-arm } \\
\text { treatment }\end{array}$ & $0.5 \mathrm{mg} / \mathrm{kg} 2 \times$ daily & 15 & $\begin{array}{l}\text { Low-dose ketamine } \\
\text { significantly reduced daily } \\
\text { morphine consumption and } \\
\text { reduced somnolence in } \\
\text { patients suffering from cancer } \\
\text { pain }\end{array}$ \\
\hline $\begin{array}{l}\text { Kannan et al. } \\
\text { (2002) }\end{array}$ & $\begin{array}{l}\text { Neuropathic cancer } \\
\text { pain }\end{array}$ & Case series & $0.5 \mathrm{mg} / \mathrm{kg} 3 \times$ daily & 9 & $\begin{array}{l}\text { Seven of nine patients report } \\
\text { decrease in pain score } \geq 3 \\
\text { compared to when solely taking } \\
\text { maximally tolerated opioid dose }\end{array}$ \\
\hline
\end{tabular}

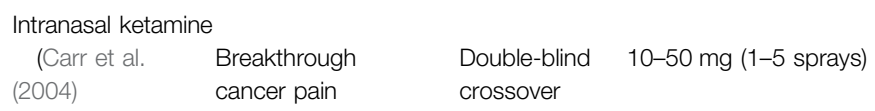

10 After treatment with intranasal ketamine, $65 \%$ of breakthrough cancer pain patients achieved an NPIS score that was at least $40 \%$ lower than pre-treatment levels compared to $20 \%$ of placebo patients

\begin{tabular}{|c|c|c|c|}
\hline \multicolumn{4}{|l|}{ Topical ketamine } \\
\hline $\begin{array}{l}\text { Finch et al. } \\
\text { (2009) }\end{array}$ & $\begin{array}{l}\text { Chronic regional } \\
\text { pain syndrome }\end{array}$ & $\begin{array}{l}\text { Double-blind } \\
\text { placebo } \\
\text { controlled }\end{array}$ & $10 \%$ ketamine cream \\
\hline $\begin{array}{l}\text { Gammaitoni } \\
\text { et al. (2000) }\end{array}$ & $\begin{array}{l}\text { CRPS, lumbar } \\
\text { radiculopathy, post- } \\
\text { herpetic neuralgia }\end{array}$ & Case series & $1 \%$ ketamine cream \\
\hline $\begin{array}{l}\text { Heir et al. } \\
(2008)\end{array}$ & $\begin{array}{l}\text { Orofacial } \\
\text { neuropathic pain }\end{array}$ & $\begin{array}{l}\text { Case-control } \\
\text { series }\end{array}$ & $\begin{array}{l}\text { 4\% KET, } 4 \% \text { carbamazepine, } \\
1 \% \text { ketoprofen, } 4 \% \\
\text { gabapentin }\end{array}$ \\
\hline $\begin{array}{l}\text { Everton et al. } \\
\text { (2007) }\end{array}$ & $\begin{array}{l}\text { Post-herpetic } \\
\text { neuralgia }\end{array}$ & $\begin{array}{l}\text { Double-blind } \\
\text { placebo } \\
\text { controlled }\end{array}$ & $\begin{array}{l}2 \% \text { ketamine }+4 \% \\
\text { amitriptyline }\end{array}$ \\
\hline
\end{tabular}

KET cream reduced CRPS associated allodynia and hyperalgesia within 30 min of administration

5

Reduction in pain scale ranging from 53-100\% 15 min after application of cream $41 \%$ of patients had a decrease in pain level of at least 30\%. This proportion is similar to systemic and systemic + topical treatment modalities $118 \quad 46 \%$ of AmiKet patients reported a decrease in daily pain score of at least 30\% compared to $19 \%$ in placebo group
Avg. Pain decrease $27 \%$ vs $2 \%$ placebo. Co-administered w/clonidine and midazolam

No significant difference in ketamine efficacy based on pain condition

Infused concomitantly w/ morphine. Only moderate side effects (dizziness)

All treatments reduced VAS score by at least $40 \%$. No differences in burning/shooting pain reduction

No somnolence reported with oral ketamine. Lower rates of adverse effects compared to morphine, nitroglycerin, and

dipyrone groups

Adverse effects: Nausea $(\times 4)$, loss of appetite $(\times 2)$, sleepiness $(\times 8$, improved to $\times 3)$. Three pts withdrew due to effects Patients on opioid therapy had lower failure rate of ketamine treatment than non-opioid group

No reports of auditory or visual hallucinations. Adverse effects: Change of taste $(\times 4)$, rhinorrhea $(\times 1)$, BP elevation $(\times 2)$

Systemic ketamine concentrations below detectable limit

No side effects reported

Pain relief lower in magnitude than systemic treatments, but shorter time to onset.

Only $5 \%$ of patients had detectable systemic ketamine or amitriptyline levels 
TABLE 3 | Compiled evidence of ketamine's analgesic effect in the pediatric population.

\begin{tabular}{|c|c|c|c|c|c|c|}
\hline References & $\begin{array}{l}\text { Pain } \\
\text { condition }\end{array}$ & Study type & $\begin{array}{l}\text { Ketamine } \\
\text { treatment }\end{array}$ & $\begin{array}{l}\text { Sample } \\
\text { size }\end{array}$ & Results & Comments \\
\hline $\begin{array}{l}\text { Bredlau et al. } \\
\text { (2013) }\end{array}$ & Chronic pain & $\begin{array}{l}\text { Prospective case } \\
\text { series }\end{array}$ & $\begin{array}{l}\text { Oral ( } 3 x \text { daily). } \\
25-1.5 \mathrm{mg} / \mathrm{kg} / \\
\text { dose }\end{array}$ & 12 & $\begin{array}{l}\text { Five of twelve children reported } \\
\text { experienced marked improvement in } \\
\text { pain scores lasting }>4 \text { weeks off } \\
\text { ketamine treatment }\end{array}$ & $\begin{array}{l}\text { Two children forced to withdraw } \\
\text { treatment due to dose-limiting toxicities }\end{array}$ \\
\hline $\begin{array}{l}\text { Finkel et al. } \\
\text { (2007) }\end{array}$ & Cancer pain & $\begin{array}{l}\text { Retrospective } \\
\text { case series }\end{array}$ & $\begin{array}{l}\text { Infusion } \\
0.1-1 \mathrm{mg} / \mathrm{kg} / \mathrm{h}\end{array}$ & 11 & $\begin{array}{l}\text { Sub-anesthetic dosages of ketamine } \\
\text { infusion resulted in subjectively } \\
\text { improved pain control and a reduction } \\
\text { in required opioid dosage ranging from } \\
28 \text { to } 100 \%\end{array}$ & $\begin{array}{l}\text { Administered with lorazepam, no } \\
\text { psychotropic effects reported. Patients } \\
\text { more awake and alert than on opioids } \\
\text { alone }\end{array}$ \\
\hline $\begin{array}{l}\text { Mulder et al. } \\
\text { (2018) }\end{array}$ & $\begin{array}{l}\text { Acute pain } \\
\text { (pancreatitis) }\end{array}$ & Case report & $\begin{array}{l}\text { Infusion } 2 \mu \mathrm{g} / \\
\mathrm{kg} / \mathrm{min}\end{array}$ & 1 & $\begin{array}{l}\text { Rapid reduction in pain score from } 8.3 \\
\text { to } 4.4 \text {. Total daily oral morphine } \\
\text { equivalent reduced from } 1,375 \text { to } \\
375 \mathrm{mg} / \text { day }\end{array}$ & $\mathrm{N} / \mathrm{A}$ \\
\hline $\begin{array}{l}\text { Weber et al. } \\
(2018)\end{array}$ & $\begin{array}{l}\text { Neuropathic } \\
\text { pain }\end{array}$ & Case report & $\begin{array}{l}\text { Infusion } 7 \mu \mathrm{g} / \\
\mathrm{kg} / \mathrm{min}\end{array}$ & 1 & $\begin{array}{l}\text { Self-reported } 70 \% \text { reduction in pain. } \\
\text { Pain relief lasted five months after initial } \\
\text { ketamine infusion }\end{array}$ & $\begin{array}{l}\text { Suicidal ideation also resolved. Patient } \\
\text { retreated at 5-months mark with same } \\
\text { results }\end{array}$ \\
\hline
\end{tabular}

\section{Ketamine Cardiovascular Effects}

Isolated human-heart studies have indicated that ketamine acts directly on cardiac myocytes as a concentration-dependent negative inotropic agent. However, due to its central inhibition of norepinephrine reuptake in adrenergic nerves it generally produces an increase in cardiac output via elevations in heart rate, systolic blood pressure, and diastolic blood pressure (Suleiman et al., 2012). In this way, ketamine acts like a sympathomimetic on the cardiovascular system although exceptions are seen with some critically-ill patients.

As evidence of the potential magnitude of this effect, a study of 20 healthy volunteers documented a $40-50 \%$ increase in total cardiac output when given intravenous infusion of ketamine at analgesic concentrations (Dahan et al., 2009).

While most examples of ketamine acting as a sympathomimetic involve intravenous infusions (largely due to the drugs use in inducing anasthesia), it is also important for analgesia purposes that the oral rout of administration does not negate this sympathomimetic effect.

A 67-year-old woman introduced to oral ketamine in the hospital for refractory chronic pain developed uncontrolled hypertension $(222 / 124 \mathrm{mmHg})$. After release, the patient was not immediately followed up with but the hypertension was found to be persistent by her GP until cessation of the oral ketamine (Van Hecke and Guthrie, 2014). These facts may make monitoring of blood pressure and other cardiovascular parameters more important if using ketamine as a long term analgesic, especially in patients who may suffer from cardiovascular disease.

\section{Ketamine Neurotoxicity}

Concern of ketamine's potential neurotoxicity arise from animal studies demonstrating that ketamine administration in rats results in dose-related and time-related increases in neuronal apoptotic cell death in the frontal cortex and other areas of the brain during development (Zou et al., 2009).

However, the validity of these studies to humans is frequently challenged. Criticism of the above (and many other ketamine neurotoxicity studies) argues the ketamine neurotoxicity observed in rat studies is not clinically relevant as the stage at which the rat studies take place is during the CNS growth spurt corresponding to 22-26 weeks gestation in humans, therefore humans would never be exposed to ketamine as ketamine is widely regarded as contraindicated $<3$ years of age (Green and Coté, 2009).

Even so, long-term treatment with ketamine does come with some documented potential for neurotoxicity. Specifically, it has been found that ketamine treated neurons are more susceptible to damage as a result endogenous glutamate release. This increased susceptibility is due to recruitment of more NMDA receptors following prolonged blockade. When activated this increased number of receptors lead to calcium overload by exceeding the buffer capacity of mitochondria and interfering with the electron transport chain resulting in production of ROS (C. Wang et al., 2017).

\section{Ketamine Addiction}

Ketamine and other members of the PCP-derivative family have a long history of drug abuse, especially by street drug users. Ketamine has even earned the street name of "Special K" due to its widespread use. Ketamine abusers are ultimately targeting the dissociative and hallucinogenic effects of the drug which are described as euphoric even in ketamine naïve subjects (Morgan et al., 2004; Domino, 2010).

The mechanism behind this addiction potential is believed to be a hijacking of the brains dopamine-based reward system. Subanesthetic doses of ketamine acutely increased extracellular concentration of dopamine in rat striatum and prefrontal cortex. Some human PET imaging also suggests that this occurs in humans. This mechanism that mimics the brain's reward system associated with addiction in other pharmaceuticals (Moghaddam et al., 1997; Smith et al., 1998).

While therapeutic doses are generally less than street-use doses, several studies detailed below detail that even when used 
medically ketamine maintains addictive potential. When healthy ketamine-naive subjects were infused with subanesthetic doses of ketamine they reported "liking" the feeling induced by ketamine and wanting more doses. In a group receiving higher doses of ketamine these cravings were relatively reduced while those on the lower dose infusions reported increasing desire for more of the drug (Morgan et al., 2004).

Another example of ketamine's addictive potential comes from a 50-year-old anesthesia nurse who was suffering from Major Depressive Disorder (MDD). The nurse initially began self-medicating with weekly IM injections of ketamine. After weeks of self-medication, the patient began to develop significant tolerance to ketamine and had to stepwise increase both dose and frequency of the ketamine. Along with tolerance, the patient also developed significant ketamine addiction. When ketamine was stopped, patient began suffering intense craving and depressive episodes (Bonnet, 2015).

While the research on ketamine's addictive potential when used medically is somewhat limited, it should not be overlooked and both physicians and patients should be aware of and discuss this potential before adoption of ketamine-based therapies.

\section{LIMITATIONS OF STUDIES}

While ketamine has been available for half a century, it has not been widely used in the medical community for decades. This has led to limited recent literature on its use, especially as an analgesic. Much of the information available on the use of ketamine for chronic pain relief is within case reports/series with relatively small sample sizes.

Unfortunately, these limited numbers provide us with limited power to determine the true efficacy of ketamine in chronic pain conditions. This may be further exacerbated by publication bias in favor of publishing reports in which ketamine is effective. Reliance on case reports also leads to the possibility of treatment effect as almost none of these reports make use of placebo or non-active controls. These shortfalls make it evident that more large-scale placebo controlled clinical trials are necessary before being able to make a statistically strong conclusion on ketamine as a long-term analgesic.

Another concern in some of the referenced studies is the possibility of confounding variables due to the large number of medications/treatments patients are often placed on prior to initiating ketamine therapy. Ketamine is currently used primarily as third-line analgesia and therefore patients are often on high-dose NSAIDs and opiates prior to trial of ketamine. This makes it hard to distinguish the singular effect of ketamine on pain relief, especially in the setting of opioid induced hyperalgesia.

Research into the adverse event profile of ketamine has also been hampered by the infrequent use of the drug in monitored clinical settings. While the papers referenced in this article provide information on the short-term development of side effects, less is known about the long-term effect of ketamine treatment. Most of what we do know about the long-term development of problems such as ketamine cystitis and hepatotoxicity has been on subjects who used ketamine as a recreational street drug and at much higher doses than used for analgesia. This raises questions as to if patients treated medically with ketamine would experience the same appearance of these symptoms.

\section{DISCUSSION}

In this article, we present ketamine as a therapy for cancer and chronic pain that is intractable to well-established therapeutics such as opioids. While ketamine has long been known as a dissociative anesthetic, its use as an analgesic agent in nonanesthetic doses is much more recent.

Ketamine's analgesic effects are believed to be an effect of NMDA-receptor blockade which decreases central neuronal excitability and therefore conduction of pain impulses. However, ketamine may also have other beneficial mechanisms of action when used to treat neuropathic pain such as the inhibition of microglial activation and neuronal inflammation as discussed above and demonstrated in several animal studies.

Ketamine has repetitively been shown to reduce pain scores and subjective measures of pain. While the use of topical ketamine alone does not have strong supporting evidence, its use in multi-agent creams has been effective in some pain conditions.

Use of ketamine has classically been associated with dissociative effects, however several recent studies have demonstrated that at sub-anesthetic dosages the occurrence of psychomimetic effects in the general population is minimal. Furthermore, the risk of these adverse events can be further reduced with pre-medication of benzodiazepines. A unique aspect of ketamine treatment in chronic pain patients is that it seems to counteract opioid-induce hyperalgesia and not therefore not only improves pain management but does so while simultaneously reducing a patient's required total daily morphine equivalent. In some instances, this has been reported to improve quality of life while in others it serves to improve respiratory and hemodynamic stability.

\section{AUTHOR CONTRIBUTIONS}

Conception and design of the study SA; combing the literature $\mathrm{CC}$ and $\mathrm{HK}$; drafting the article $\mathrm{CC}$ and $\mathrm{HK}$; revisions for content $\mathrm{CC}, \mathrm{HK}$, and SA; and critical revisions for important intellectual content SA. All authors contributed to the article and approved the submitted version.

\section{FUNDING}

This work was supported by grants from the Helen Buchanan and Stanley Joseph Seeger Endowment at The University of Texas MD Anderson Cancer Center to SA. 


\section{REFERENCES}

Adler, C. M., Goldberg, T. E., Malhotra, A. K., Pickar, D., and Breier, A. (1998). Effects of ketamine on thought disorder, working memory, and semantic memory in healthy volunteers. Biol. Psychiatr. 43 (11), 811-816. doi:10. 1016/S0006-3223(97)00556-8

Bansinath, M., Warner, W., Tang, C. K., Turndorf, H., and Puig, M. M. (1992). On the mechanism of the interaction of ketamine and halothane in vitro. Gen. Pharmacol. 23 (6), 1183-1187. doi:1016/0306-3623(92)90309-8

Bell, R. F., Eccleston, C., and Kalso, E. A. (2017). "Ketamine as an adjuvant to opioids for cancer pain. Cochrane Database Syst. Rev. 2017 (Issue 6), CD003351. doi:10.1002/14651858.CD003351.pub3

Bonnet, U. (2015). Long-term ketamine self-injections in major depressive disorder: focus on tolerance in ketamine's antidepressant response and the development of ketamine addiction. J. Psychoact. Drugs. 47 (4), 276-285. doi:10. 1080/02791072.2015.1072653

Bredlau, A. L., McDermott, M. P., Adams, H. R., Dworkin, R. H., Venuto, C., Fisher, S. G., et al. (2013). Oral ketamine for children with chronic pain: a pilot phase 1 study. J. Pediatr. 163 (1), 194. doi:10.1016/j.jpeds.2012. 12.077

Breier, A., Malhotra, A. K., Pinals, D. A., Weisenfeld, N. I., and Pickar, D. (1997). Association of ketamine-induced psychosis with focal activation of the prefrontal cortex in healthy volunteers. Am. J. Psychiatr. 154 (6), 805-811. doi:10.1176/ajp.154.6.805

Burton, A. W., Lee, DH, Saab, C, and Chung, JM (1999). Preemptive intrathecal ketamine injection produces a long-lasting decrease in neuropathic pain behaviors in a rat model. Reg. Anesth. Pain Med. 24 (3), 208-213. doi:10. 1016/S1098-7339(99)90129-3

Carr, D. B., Goudas, L. C., Denman, W. T., Brookoff, D., Staats, P. S., Brennen, L., et al. (2004). Safety and efficacy of intranasal ketamine for the treatment of breakthrough pain in patients with chronic pain: a randomized, double-blind, placebo-controlled, crossover study. Pain 108 (1-2), 17-27. doi:10.1016/j.pain. 2003.07.001

Choi, E., Lee, H., Park, H. S., Lee, G. Y., Kim, Y. J., and Baik, H. J. (2015). Effect of intraoperative infusion of ketamine on remifentanil-induced hyperalgesia. Korean J Anesthesiol. 68 (5), 476-480. doi:10.4097/kjae.2015.68.5.476

Christoph, T., Schiene, K., Englberger, W., Parsons, C. G., and Chizh, B. A. (2006). The antiallodynic effect of NMDA antagonists in neuropathic pain outlasts the duration of the in vivo NMDA antagonism. Neuropharmacology 51 (1), 12-17. doi:10.1016/j.neuropharm.2006.02.007

Chung, S. M. (2009). Peripheral NMDA receptors revisited - hope floats. Pain 146, 1-2. doi:10.1016/j.pain.2009.08.011

Claudino, R., Nones, C., Araya, E., and Chichorro, J. (2018). Analgesic effects of intranasal ketamine in rat models of facial pain. J. Oral Facial Pain Headache 32 (3), 238-246. doi:10.11607/ofph.1973

Coggeshall, R. E., and Carlton, S. M. (1998). Ultrastructural analysis of NMDA, AMPA, and kainate receptors on unmyelinated and myelinated axons in the periphery. J. Comp. Neurol. 391, 78-86. doi:10.1002/(sici)1096-9861(19980202) 391:1<78::aid-cne7>3.3.co;2-8

Cohen, S. P., Bhatia, A., Buvanendran, A., Schwenk, E. S., Wasan, A. D., Hurley, R. W., et al. (2018). Consensus guidelines on the use of intravenous ketamine infusions for chronic pain from the American society of regional anesthesia and pain medicine, the American academy of pain medicine, and the American society of anesthesiologists. Reg. Anesth. Pain Med. 43 (Issue 5), 521-546. doi:10.1097/AAP.0000000000000808

Cohen, S. P., Chang, A. S., Larkin, T., and Mao, J. (2004). The intravenous ketamine test: a predictive response tool for oral dextromethorphan treatment in neuropathic pain. Anesth. Analg. 99 (6), 1753-1759. doi:10.1213/01.ANE. 0000136953.11583.7B

Cohen, S. P., Verdolin, M. H., Chang, A. S., Kurihara, C., Morlando, B. J., and Mao, J. (2006). The intravenous ketamine test predicts subsequent response to an oral dextromethorphan treatment regimen in fibromyalgia patients. J. Pain. 7 (6), 391-398. doi:10.1016/j.jpain.2005.12.010

Cohen, S. P., Wang, S., Chen, L., Kurihara, C., McKnight, G., Marcuson, M., et al. (2009). An intravenous ketamine test as a predictive response tool in opioidexposed patients with persistent pain. J. Pain Symptom Manag. 37 (4), 698-708. doi:10.1016/j.jpainsymman.2008.03.018
Crisp, T., Perrotti, J. M., Smith, D. L., Stafinsky, J. L., and Smith, D. J. (1991). The local monoaminergic dependency of spinal ketamine. Eur. J. Pharmacol. 194(23), 167-172. doi:10.1016/0014-2999(91)90101-U

Dahan, A., Olofsen, E., Sigtermans, M., Noppers, I., Niesters, M., Aarts, L., et al. (2011). Population pharmacokinetic-pharmacodynamic modeling of ketamine-induced pain relief of chronic pain. Eur. J. Pain. 15 (3), 258-267. doi:10.1016/j.ejpain.2010.06.016

de Barros, G. A. M., Miot, H. A., Braz, A. M., Ramos, F., and Borges, M. A. (2012). (S)-cetamina tópica no tratamento da dor da neuralgia pós-herpética. An. Bras. Dermatol. 87 (3), 504-505. doi:10.1590/S0365-05962012000300032

Dolansky, G., Shah, A., Mosdossy, G., and Rieder, M. (2008). What is the evidence for the safety and efficacy of using ketamine in children? Paediatr. Child Health. 13 (Issue 4), 307-308. doi:10.1093/pch/13.4.307

Domino, E. F., Domino, S. E., Smith, R. E., Domino, L. E., Goulet, J. R., Domino, K. E., et al. (1984). Ketamine kinetics in unmedicated and diazepam-premedicated subjects. Clin. Pharmacol. Ther. 36 (5), 645-653. doi:10.1038/clpt.1984.235

Domino, E. F., Chodoff, P., and Corssen, G. (1965). Pharmacologic effects of CI581, a new dissociative anesthetic, in man. Clin. Pharmacol. Ther. 6, 279-291. doi:10.1002/cpt196563279

Domino, E. F. (2010). Taming the ketamine tiger. 1965. Anesthesiology 113 (3), 678-684. doi:10.1097/ALN.0b013e3181ed09a2

Durieux, M. E. (1995). Inhibition by ketamine of muscarinic acetylcholine receptor function. Anesth. Analg. 81 (1). https://journals.lww.com/anesthesia-analgesia/ Fulltext/1995/07000/Inhibition_by_Ketamine_of_Muscarinic_Acetylcholine.12.aspx

Everton, D., Bhagwat, D., and Damask, M. (2007). A multicenter, double-blind, randomized, placebo controlled study of the efficacy/safety of two doses of amitriptyline/ketamine topical cream in treating post-herpetic neuralgia. J. Pain 8 (4), S47. doi:10.1016/j.jpain.2007.02.192

Finch, P. M., Knudsen, L., and Drummond, P. D. (2009). Reduction of allodynia in patients with complex regional pain syndrome: a double-blind placebocontrolled trial of topical ketamine. Pain 146 (1-2), 18-25. doi:10.1016/j. pain.2009.05.017

Finkel, J. C., Pestieau, S. R., and Quezado, Z. M. (2007). Ketamine as an adjuvant for treatment of cancer pain in children and adolescents. J. Pain 8 (6), 515-521. doi:10.1016/j.jpain.2007.02.429

Gammaitoni, A., Gallagher, R. M., and Welz-Bosna, M. (2000). Topical ketamine gel: possible role in treating neuropathic pain. Pain Med. 1 (1), 97-100. doi:10. 1046/j.1526-4637.2000.00006.x

Gautam, C., Mahajan, S., Sharma, J., Singh, H., and Singh, J. (2020). Repurposing potential of ketamine: opportunities and challenges. Indian J. Psychol. Med. 42 (Issue 1), 22-29. doi:10.4103/IJPSYM.IJPSYM_228_19

Gewandter, J. S., Mohile, S. G., Heckler, C. E., Ryan, J. L., Kirshner, J. J., Flynn, P. J., et al. (2014). A phase III randomized, placebo-controlled study of topical amitriptyline and ketamine for chemotherapy-induced peripheral neuropathy (CIPN): a University of Rochester CCOP study of 462 cancer survivors. Support. Care Canc. 22 (7), 1807-1814. doi:10.1007/s00520-014-2158-7

Gharaei, B., Jafari, A., Aghamohammadi, H., Kamranmanesh, M., Poorzamani, M., Elyassi, H., Rostamian, B., and Salimi, A. (2013). Opioid-sparing effect of preemptive bolus low-dose ketamine for moderate sedation in opioid abusers undergoing extracorporeal shock wave lithotripsy. Anesth. Analg. 116 (1), 75-80. doi:10.1213/ANE.0b013e31826f0622

Green, S. M., and Coté, C. J. (2009). Ketamine and neurotoxicity: clinical perspectives and implications for emergency medicine. Ann. Emerg. Med. 54 (2), 181-190. doi:10.1016/j.annemergmed.2008.10.003

Green, S. M., and Krauss, B. (2004). Clinical practice guideline for emergency department ketamine dissociative sedation in children. Ann. Emerg. Med. 44 (5), 460-471. doi:10.1016/j.annemergmed.2004.06.00610.1016/S0196064404006365

Hagelberg, N. M., Peltoniemi, M. A., Saari, T. I., Kurkinen, K. J., Laine, K., Neuvonen, P. J., et al. (2010). Clarithromycin, a potent inhibitor of CYP3A, greatly increases exposure to oral S-ketamine. Eur. J. Pain 14 (6), 625-629. doi:10.1016/j.ejpain.2009.10.003

Harborne, G. C., Watson, F. L., Healy, D. T., and Groves, L. n. d.) (1996). The effects of sub-anaesthetic doses of ketamine on memory, cognitive performance and subjective experience in healthy volunteers. J. Psychopharmacol. 10 (2), 134-140. doi:10.1177/026988119601000208

Hayashi, Y., Kawaji, K., Sun, L., Zhang, X., Koyano, K., Yokoyama, T., et al. (2011). Microglial $\mathrm{Ca}(2+)$-activated $\mathrm{K}(+)$ channels are possible molecular targets for the analgesic effects of S-ketamine on neuropathic pain. J. Neurosci. 31 (48), 17370-17382. doi:10.1523/JNEUROSCI.4152-11.2011 
Heir, G., Karolchek, S., Kalladka, M., Vishwanath, A., Gomes, J., Khatri, R., et al. (2008). Use of topical medication in orofacial neuropathic pain: a retrospective study. Oral Surg. Oral Med. Oral Pathol. Oral Radiol. Endod. 105 (4), 466-469. doi:10.1016/j.tripleo.2007.09.030

Hijazi, Y., and Boulieu, R. (2002). Contribution of CYP3A4, CYP2B6, and CYP2C9 isoforms to N-demethylation of ketamine in human liver microsomes. Drug Metab. Dispos. 30 (7), 853-858. doi:10.1124/dmd.30.7.853

Hwang, B. Y., Kim, E. S., Kim, C. H., Kwon, J. Y., and Kim, H. K. (2012). Gender differences in paclitaxel-induced neuropathic pain behavior and analgesic response in rats. Korean J. Anesthesiol. 62 (1), 66-72. doi:10.4097/kjae.2012. 62.1 .66

Idvall, J., Aronsen, K. F., Stenberg, P., and Paalzow, L. (1983). Pharmacodynamic and pharmacokinetic interactions between ketamine and diazepam. Eur. J. Clin. Pharmacol. 24 (3), 337-343. doi:10.1007/BF00610051

Jhang, J. F., Hsu, Y. H., Jiang, Y. H., and Kuo, H. C. (2014). Elevated serum IgE may be associated with development of ketamine cystitis. J. Urol. 192 (4), 1249-1256. doi:10.1016/j.juro.2014.05.084

Jhang, J. F., Hsu, Y. H., and Kuo, H. C. (2015). Possible pathophysiology of ketamine-related cystitis and associated treatment strategies. Int. J. Urol. 22 (9), 816-825. doi:10.1111/iju.12841

Kannan, T. R., Saxena, A., Bhatnagar, S., and Barry, A. (2002). Oral ketamine as an adjuvant to oral morphine for neuropathic pain in cancer patients. J. Pain Symptom Manag. 23 (1), 60-65. doi:10.1016/S0885-3924(01)00373-6

Kapur, S., and Seeman, P. (2002). NMDA receptor antagonists ketamine and PCP have direct effects on the dopamine D2 and serotonin 5-HT2 receptors implications for models of schizophrenia. Mol. Psychiatry, 7 (8), 837-844. doi:10.1038/sj.mp.4001093

Kharasch, E. D., and Labroo, R. (1992). Metabolism of ketamine stereoisomers by human liver microsomes. Anesthesiology 77 (6), 1201-1207. doi:10.1097/ 00000542-199212000-00022

Kiefer, R. T., Rohr, P., Ploppa, A., Dieterich, H. J., Grothusen, J., Koffler, S., et al. (2008). Efficacy of ketamine in anesthetic dosage for the treatment of refractory complex regional pain syndrome: an open-label phase II study. Pain Med. 9 (8), 1173-1201. doi:10.1111/j.1526-4637.2007.00402.x

Kim, S. H., Kim, S. I., Ok, S. Y., Park, S. Y., Kim, M. G., Lee, S. J., et al. (2013). Opioid sparing effect of low dose ketamine in patients with intravenous patientcontrolled analgesia using fentanyl after lumbar spinal fusion surgery. Korean J. Anesthesiol. 64 (6), 524-528. doi:10.4097/kjae.2013.64.6.524

Kohrs, R., and Durieux, M. E. (1998). Ketamine: teaching an old drug new tricks. Anesth. Analg. 87 (5), 1186-1193. doi:10.1213/00000539-199811000-00039

Kronenberg, R. H. (2002). Ketamine as an analgesic: parenteral, oral, rectal, subcutaneous, transdermal and intranasal administration. J. Pain Palliat. Care Pharmacother. 16 (3), 27-35. doi:10.1080/J354v16n03_03

Krystal, J. H., D’Souza, D. C., Karper, L. P., Bennett, A., Abi-Dargham, A., AbiSaab, D., et al. (1999). Interactive effects of subanesthetic ketamine and haloperidol in healthy humans. Psychopharmacology 145 (2), 193-204. doi:10.1007/s002130051049

Kwon, S. Y., Yeom, J. H., and Joo, J. D. (2014). Ketamine reduces the induced spinal p38 MAPK and pro-inflammatory cytokines in a neuropathic rats. Korean J. Anesthesiol. 66 (1), 52-58. doi:10.4097/kjae.2014.66.1.52

Lahti, A. C., Weiler, M. A., Tamara Michaelidis, B. A., Parwani, A., and Tamminga, C. A. (2001). Effects of ketamine in normal and schizophrenic volunteers. Neuropsychopharmacology 25 (4), 455-467. doi:10.1016/S0893-133X(01) 00243-3

Lauretti, G. R., Lima, I. C., Reis, M. P., Prado, W. A., and Pereira, N. L. (1999). Oral ketamine and transdermal nitroglycerin as analgesic adjuvants to oral morphine therapy for cancer pain management. Anesthesiology 90 (6), 1528-1533. doi:10.1097/00000542-199906000-00005

Lee, M., Silverman, S. M., Hansen, H., Patel, V. B., Manchikanti, L., and Manchikanti, L. (2011). A comprehensive review of opioid-induced hyperalgesia. Pain Physician. 14, 145-161. 10.5055/jom.2017.0373

Li, Y., Coller, J. K., Hutchinson, M. R., Klein, K., Zanger, U. M., Stanley, N. J., et al. (2013). The CYP2B6*6 allele significantly alters the $\mathrm{N}$-demethylation of ketamine enantiomers in vitro. Drug Metab. Dispos. 41 (6), 1264-1272. doi:10.1124/dmd.113.051631

Li, Y., Jackson, K. A., Slon, B., Hardy, J. R., Franco, M., William, L., et al. (2015). CYP2B $6{ }^{*} 6$ allele and age substantially reduce steady-state ketamine clearance in chronic pain patients: impact on adverse effects. Br. J. Clin. Pharmacol. 80 (2), 276-284. doi:10.1111/bcp.12614

Liao, Y., Tang, J., Corlett, P. R., Wang, X., Yang, M., Chen, H., et al. (2011). Reduced dorsal prefrontal gray matter after chronic ketamine use. Biol. Psychiatr. 69 (1), 42-48. doi:10.1016/j.biopsych.2010.08.030

Liao, Y., Tang, J., Ma, M., Wu, Z., Yang, M., Wang, X., et al. (2010). Frontal white matter abnormalities following chronic ketamine use: a diffusion tensor imaging study. Brain 133 (7), 2115-2122. doi:10.1093/brain/awq131

Lim, H. S., Kim, J. M., Choi, J. G., Ko, Y. K., Shin, Y. S., Jeon, B. H., et al. (2013). Intrathecal ketamine and pregabalin at sub-effective doses synergistically reduces neuropathic pain without motor dysfunction in mice. Biol. Pharm. Bull. 36 (1), 125-130. doi:10.1248/bpb.b12-00760

Liman, S., Wai Cheung, C., Lok Wong, K., Tai, W., Qiu, Q., Fu Ng, K., et al. (2015). Preventive treatment with ketamine attenuates the ischaemia-reperfusion response in a chronic postischaemia pain model. doi:10.1155/2015/380403

Lossignol, D. A., Obiols-Portis, M., and Body, J. J. (2005). Successful use of ketamine for intractable cancer pain. Support. Care Canc. 13 (3), 188-193. doi:10.1007/s00520-004-0684-4

Lynch, M. E., Clark, A. J., and Sawynok, J. (2003). A pilot study examining topical amitriptyline, ketamine, and a combination of both in the treatment of neuropathic pain. Clin. J. Pain. 19 (5), 323-328. doi:10.1097/00002508200309000-00007

Lynch, M. E., Clark, A. J., Sawynok, J., and Sullivan, M. J. (2005). Topical 2\% amitriptyline and $1 \%$ ketamine in neuropathic pain syndromes: a randomized, double-blind, placebo-controlled trial. Anesthesiology 103 (1), 140-146. doi:10. 1097/00000542-200507000-00021

Mak, P., Broadbear, J. H., Kolosov, A., and Goodchild, C. S. (2015). Long-term antihyperalgesic and opioid-sparing effects of 5-day ketamine and morphine infusion ("Burst ketamine") in diabetic neuropathic rats. Pain Med. 16 (9), 1781-1793. doi:10.1111/pme.12735

Marchetti, F., Coutaux, A., Bellanger, A., Magneux, C., Bourgeois, P., and Mion, G. (2014). Efficacy and safety of oral ketamine for the relief of intractable chronic pain: a retrospective 5-year study of 51 patients. Eur. J. Pain 9 (7), 984-993. doi:10.1002/ejp.624

Mathisen, L. C., Skjelbred, P., Skoglund, L. A., and Øye, I. (1995). Effect of ketamine, an NMDA receptor inhibitor, in acute and chronic orofacial pain. Pain 61 (2), 215-220. doi:10.1016/0304-3959(94)00170-J

Mei, X., Wang, W., Wang, W., Li, Y., Zhang, H., Wu, S., et al. (2009). Inhibiting astrocytic activation: a novel analgesic mechanism of ketamine at the spinal level? J. Neurochem. 109 (6), 1691-1700. doi:10.1111/j.1471-4159.2009.06087.x

Mei, X. P., Wang, W., Wang, W., Zhu, C., Chen, L., Zhang, T., et al. (2010). Combining ketamine with astrocytic inhibitor as a potential analgesic strategy for neuropathic pain ketamine, astrocytic inhibitor and pain. Mol. Pain 6, 50. doi:10.1186/1744-8069-6-50

Mei, X. P., Zhang, H., Wang, W., Wei, Y. Y., Zhai, M. Z., Wang, W., et al. (2011a). Inhibition of spinal astrocytic c-Jun N-terminal kinase (JNK) activation correlates with the analgesic effects of ketamine in neuropathic pain. J. Neuroinflam. 8, 6. doi:10.1186/1742-2094-8-6

Mei, X. P., Zhou, Y., Wang, W., Tang, J., Wang, W., Zhang, H., et al. (2011b). Ketamine depresses toll-like receptor 3 signaling in spinal microglia in a rat model of neuropathic pain. Neurosignals 19 (1), 44-53. doi:10.1159/ 000324293

Mercadante, S., Lodi, F., Sapio, M., Calligara, M., and Serretta, R. (1995). Longterm ketamine subcutaneous continuous infusion in neuropathic cancer pain. J. Pain Symptom Manag. 10 (7), 564-568. doi:10.1016/0885-3924(95)00102-5

Mika, J., Osikowicz, M., Rojewska, E., Korostynski, M., Wawrzczak-Bargiela, A., Przewlocki, R., et al. (2009). Differential activation of spinal microglial and astroglial cells in a mouse model of peripheral neuropathic pain. Eur. J. Pharmacol. 623 (1-3), 65-72. doi:10.1016/j.ejphar.2009.09.030

Mion, G., and Villevieille, T. (2013). Ketamine pharmacology: an update (pharmacodynamics and molecular aspects, recent findings). CNS Neurosci. Ther. 19 (Issue 6), 370-380. doi:10.1111/cns.12099

Moghaddam, B., Adams, B., Verma, A., and Daly, D. (1997). Activation of glutamatergic neurotransmission by ketamine: a novel step in the pathway from NMDA receptor blockade to dopaminergic and cognitive disruptions associated with the prefrontal cortex. J. Neurosci. 17 (8), 2921-2927. doi:10. 1523/jneurosci.17-08-02921.1997 
Morgan, C. J., Mofeez, A., Brandner, B., Bromley, L., and Curran, H. V. (2004). Ketamine impairs response inhibition and is positively reinforcing in healthy volunteers: a dose-response study. Psychopharmacology 172 (3), 298-308. doi:10.1007/s00213-003-1656-y

Morley, J. S. (2003). Low-dose methadone has an analgesic effect in neuropathic pain: a double-blind randomized controlled crossover trial. Palliat. Med. 17 (7), 576-587. doi:10.1191/0269216303pm815oa

Mulder, D. J., Sherlock, M. E., and Lysecki, D. L. (2018). NMDA-receptor antagonism in pediatric pancreatitis: use of ketamine and methadone in a teenager with refractory pain. J. Pediatr. Gastroenterol. Nutr. 66 (5), e134-e136. doi:10.1097/MPG.0000000000001907

Nina Dimitrova, D., Liliya, V., Kremena, S., Darinka, D., and Damyanka, G. (2019). Study of antinociceptive effect of ketamine in acute and neuropathic pain models in rats. Adv. Clin. Exp. Med. 28 (5), 573-579. doi:10.17219/ACEM/ 94143

Niesters, M., Martini, C., and Dahan, A. (2014). Ketamine for chronic pain: risks and benefits. Br. J. Clin. Pharmacol. 77 (2), 357-367. doi:10.1111/bcp. 12094

Noppers, I. M., Niesters, M., Aarts, L. P., Bauer, M. C., Drewes, A. M., Dahan, A., et al. (2011). Drug-induced liver injury following a repeated course of ketamine treatment for chronic pain in CRPS type 1 patients: a report of 3 cases. Pain 152 (9), 2173-2178. doi:10.1016/j.pain.2011.03.026

Orhurhu, V., Orhurhu, M. S., Bhatia, A., and Cohen, S. P. (2019). Ketamine infusions for chronic pain: a systematic review and meta-analysis of randomized controlled trials. Anesth. Analg. 129 (Issue 1), 241-254. doi:10. 1213/ANE.0000000000004185

Pascual, D., Goicoechea, C., Burgos, E., and Martín, M. I. (2010). Antinociceptive effect of three common analgesic drugs on peripheral neuropathy induced by paclitaxel in rats. Pharmacol. Biochem. Behav. 95 (3), 331-337. doi:10.1016/j. pbb.2010.02.009

Pelissier, T., Laurido, C., Kramer, V., Hernández, A., and Paeile, C. (2003). Antinociceptive interactions of ketamine with morphine or methadone in mononeuropathic rats. Eur. J. Pharmacol. 477 (1), 23-28. doi:10.1016/ S0014-2999(03)02192-7

Peltoniemi, M. A., Saari, T. I., Hagelberg, N. M., Laine, K., Kurkinen, K. J., Neuvonen, P. J., et al. (2012a). Rifampicin has a profound effect on the pharmacokinetics of oral S-ketamine and less on intravenous S-ketamine. Basic Clin. Pharmacol. Toxicol. 111 (5), 325-332. doi:10.1111/j.1742-7843. 2012.00908.x

Peltoniemi, M. A., Saari, T. I., Hagelberg, N. M., Laine, K., Neuvonen, P. J., and Olkkola, K. T. (2012b). S-ketamine concentrations are greatly increased by grapefruit juice. Eur. J. Clin. Pharmacol. 68 (6), 979-986. doi:10.1007/s00228012-1214-9

Qian, J., Brown, S. D., and Carlton, S. M. (1996). Systemic ketamine attenuates nociceptive behaviors in a rat model of peripheral neuropathy. Brain Res. 715 (1-2), 51-62. doi:10.1016/0006-8993(95)01452-7

Rigo, F. K., Trevisan, G., Godoy, M. C., Rossato, M. F., Dalmolin, G. D., Silva, M. A., et al. (2017). Management of neuropathic chronic pain with methadone combined with ketamine: a randomized, double blind, active-controlled clinical trial. Pain Physician. 20 (3), 207-215. doi:10.36076/ppj.2017.215

Rosenbaum, S. B., Gupta, V., and Palacios, J. L. (2020). "Ketamine," in StatPearls. Treasure Island, FL: StatPearls Publishing

Sasaki, A., Serizawa, K., Andoh, T., Shiraki, K., Takahata, H., and Kuraishi, Y. (2008). Pharmacological differences between static and dynamic allodynia in mice with herpetic or postherpetic pain. J. Pharmacol. Sci. 108 (3), 266-273. doi:10.1254/jphs.08154FP

Schwartzman, R. J., Alexander, G. M., Grothusen, J. R., Paylor, T., Reichenberger, E., and Perreault, M. (2009). Outpatient intravenous ketamine for the treatment of complex regional pain syndrome: a double-blind placebo controlled study. Pain 147 (1-3), 107-115. doi:10.1016/j.pain.2009.08.015

Schwenk, E. S., Goldberg, S. F., Patel, R. D., Zhou, J., Adams, D. R., Baratta, J. L., et al. (2016). Adverse drug effects and preoperative medication factors related to perioperative low-dose ketamine infusions. Reg. Anesth. Pain Med. 41 (4), 482-487. doi:10.1097/AAP.0000000000000416

Shibakawa, Y. S., Sasaki, Y., Goshima, Y., Echigo, N., Kamiya, Y., Kurahashi, K., et al. (2005). Effects of ketamine and propofol on inflammatory responses of primary glial cell cultures stimulated with lipopolysaccharide. Br. J. Anaesth. 95 (6), 803-810. doi:10.1093/bja/aei256
Sigtermans, M., Dahan, A., Mooren, R., Bauer, M., Kest, B., Sarton, E., et al. (2009). $\mathrm{S}(+)$-ketamine effect on experimental pain and cardiac output: a population pharmacokinetic-pharmacodynamic modeling study in healthy volunteers. Anesthesiology 111 (4), 892-903. doi:10.1097/ALN.0b013e3181b437b1

Sinner, B., and Graf, B. M. (2008). Ketamine BT-modern anesthetics. Editors J. Schüttler and H. Schwilden (Springer Berlin Heidelberg), 313-333.

Sleigh, J., Harvey, M., Voss, L., and Denny, B. (2014). Ketamine-more mechanisms of action than just NMDA blockade. Trends Anaesth. Crit. Care 4 (Issues 2-3), 76-81. doi:10.1016/j.tacc.2014.03.002

Smith, G. S., Schloesser, R., Brodie, J. D., Dewey, S. L., Logan, J., Vitkun, S. A., et al. (1998). Glutamate modulation of dopamine measured in vivo with positron emission tomography (PET) and 11C-raclopride in normal human subjects. Neuropsychopharmacology 18 (1), 18-25. doi:10.1016/S0893133X(97)00092-4

Staff, T. P. O. (2015). Correction: spinal cord transection-induced allodynia in rats - behavioral, physiopathological and pharmacological characterization. PloS One 10 (3), e0117868. doi:10.1371/journal.pone.0117868

Stoker, A. D., Rosenfeld, D. M., Buras, M. R., Alvord, J. M., and Gorlin, A. W. (2019). Evaluation of clinical factors associated with adverse drug events in patients receiving sub-anesthetic ketamine infusions. J. Pain Res. 12, 3413-3421. doi:10.2147/JPR.S217005

Suleiman, Z., Ik, K., and Bo, B. (2012). Evaluation of the cardiovascular stimulation effects after induction of anaesthesia with ketamine. J. West Afr. Coll. Surg. 2 (1), 38-52.

Suzuki, R., Matthews, E. A., and Dickenson, A. H. (2001). Comparison of the effects of MK-801, ketamine and memantine on responses of spinal dorsal horn neurones in a rat model of mononeuropathy. Pain 91 (1-2), 101-109. doi:10. 1016/S0304-3959(00)00423-1

Swartjes, M., Morariu, A., Niesters, M., Aarts, L., and Dahan, A. (2011). Nonselective and NR2B-selective N-methyl-d-aspartic acid receptor antagonists produce antinociception and long-term relief of allodynia in acute and neuropathic pain. Anesthesiology 115 (1), 165-174. doi:10.1097/ ALN.0b013e31821bdb9b

Tajerian, M., Leu, D., Yang, P., Huang, T. T., Kingery, W. S., and Clark, J. D. (2015). Differential efficacy of ketamine in the acute versus chronic stages of complex regional pain syndrome in mice. Anesthesiology 123 (6), 1435-1447. doi:10. 1097/ALN.0000000000000889

Uchaipichat, V., Raungrut, P., Chau, N., Janchawee, B., Evans, A. M., and Miners, J. O. (2011). Effects of ketamine on human UDP-glucuronosyltransferases in vitro predict potential drug-drug interactions arising from ketamine inhibition of codeine and morphine glucuronidation. Drug Metab. Dispos. 39 (8), 1324-1328. doi:10.1124/dmd.111.039727

Van Hecke, O., and Guthrie, B. (2014). Oral ketamine analgesia in chronic pain and problematic rise in blood pressure. BMJ Case Rep. 2014, bcr2014207836. doi:10. 1136/bcr-2014-207836

Vega-Avelaira, D., McKelvey, R., Hathway, G., and Fitzgerald, M. (2012). The emergence of adolescent onset pain hypersensitivity following neonatal nerve injury. Mol. Pain 8, 30. doi:10.1186/1744-8069-8-310.1186/1744-8069-8-30

Vissers, K. C., Geenen, F., Biermans, R., and Meert, T. F. (2006). Pharmacological correlation between the formalin test and the neuropathic pain behavior in different species with chronic constriction injury. Pharmacol. Biochem. Behav. 84 (3), 479-486. doi:10.1016/j.pbb.2006.06.011

Wang, C., Liu, F., Patterson, T. A., Paule, M. G., and Slikker, W. (2017). Relationship between ketamine-induced developmental neurotoxicity and NMDA receptor-mediated calcium influx in neural stem cell-derived neurons. Neurotoxicology 60, 254-259. doi:10.1016/j.neuro.2016.04.015

Wang, J., Goffer, Y., Xu, D., Tukey, D. S., Shamir, D. B., Eberle, S. E., et al. (2011). A single subanesthetic dose of ketamine relieves depression-like behaviors induced by neuropathic pain in rats. Anesthesiology 115 (4), 812-821. doi:10.1097/ALN.0b013e31822f16ae

Ward, J., and Standage, C. (2003). Angina pain precipitated by a continuous subcutaneous infusion of ketamine, J. Pain Symptom Manag. 25 (Issue 1), 6-7. doi:10.1016/S0885-3924(02)00603-6

Watkins, L. R., Milligan, E. D., and Maier, S. F. (2001). Glial activation: a driving force for pathological pain. Trends Neurosci. 24 (Issue 8), 450-455. doi:10.1016/ S0166-2236(00)01854-3

Weber, G., Yao, J., Binns, S., and Namkoong, S. (2018). Case report of subanesthetic intravenous ketamine infusion for the treatment of neuropathic pain and 
depression with suicidal features in a pediatric patient. Case Report 2018, 9375910. doi:10.1155/2018/9375910

White, J., and Kershaw, S. (2015). Ketamine (INN) update review report agenda item 6.1 expert committee on drug dependence thirty-seventh meeting. Available at: https://www.who.int/medicines/access/controlled-substances/6_1_Ketamine_ Update_Review.pdf?ua $=1$

Winegarden, J., Carr, D. B., and Bradshaw, Y. S. (2016). Intravenous ketamine for rapid opioid dose reduction, reversal of opioid-induced neurotoxicity, and pain control in terminal care: case report and literature review. Pain Med. 17 (4), pme12865. doi:10.1111/pme.12865

Winstock, A. R., Mitcheson, L., Gillatt, D. A., and Cottrell, A. M. (2012). The prevalence and natural history of urinary symptoms among recreational ketamine users. $B J U$ Int. 110 (11), 1762-1766. doi:10.1111/j.1464-410X.2012.11028.x

Xu, K., Krystal, J. H., Ning, Y., Chen, D. C., He, H., Wang, D., et al. (2015). Preliminary analysis of positive and negative syndrome scale in ketamineassociated psychosis in comparison with schizophrenia. J. Psychiatr. Res. 61, 64-72. doi:10.1016/j.jpsychires.2014.12.012

Zheng, X., Fang, P., Bao, S. S., Lin, D., Cai, J. P., and Hu, G. X. (2017). Function of 38 variants CYP2C9 polymorphism on ketamine metabolism in vitro. J. Pharmacol. Sci. 135 (1), 8-13. doi:10.1016/j.jphs.2017.08.006
Zhou, H., Zhang, Q., Martinez, E., Dale, J., Hu, S., Zhang, E., et al. (2018). Ketamine reduces aversion in rodent pain models by suppressing hyperactivity of the anterior cingulate cortex. Nat. Commun. 9 (1), 1-13. doi:10.1038/s41467-018-06295-x

Zou, X., Patterson, T. A., Sadovova, N., Twaddle, N. C., Doerge, D. R., Zhang, X., et al. (2009). Potential neurotoxicity of ketamine in the developing rat brain. Toxicol. Sci. 108 (1), 149-158. doi:10.1093/ toxsci/kfn 270

Conflict of Interest: The authors declare that the research was conducted in the absence of any commercial or financial relationships that could be construed as a potential conflict of interest.

Copyright $\odot 2021$ Culp, Kim and Abdi. This is an open-access article distributed under the terms of the Creative Commons Attribution License (CC BY). The use, distribution or reproduction in other forums is permitted, provided the original author(s) and the copyright owner(s) are credited and that the original publication in this journal is cited, in accordance with accepted academic practice. No use, distribution or reproduction is permitted which does not comply with these terms. 